\title{
5. QUATERNARY STRATIGRAPHY AND PLANKTONIC FORAMINIFERS OF THE EASTERN ATLANTIC, DEEP SEA DRILLING PROJECT, LEG 41
}

\author{
Uwe Pflaumann, Geologisch-Paläontologisches Institut der Universität Kiel, Olshausenstr. 40/60, 23 Kiel, \\ Federal Republic of Germany \\ and \\ Valery A. Krasheninnikov, Geological Institute of the USSR Academy of Sciences, Moscow, USSR
}

\section{SUMMARY}

Quaternary sediments have been recovered at all five sites of Leg 41 (Figure 1). Planktonic foraminifers are abundant and well preserved. Holes 366A (Sierra Leone Rise) and 368 (Cape Verde Rise) are most important for stratigraphy. The faunas are attributed to the tropical-subtropical province marked by the dominance of species of Globigerinoides, Globorotalia, and Orbulina. Cooler conditions are indicated at Site 368 by the elevated amounts of Globigerina and the presence of Globorotalia inflata.

We distinguished 54 planktonic foraminifer species and subspecies in Quaternary faunas, some of them with restricted ranges. They have been used for a subdivision of the Quaternary, using the subzonation scheme of Bolli and Premoli Silva (1973). Difficulties arise in the precise positioning of the subzonal boundaries, as there are transitions between the zonal markers and their ancestors, or the zonal markers are rare or undeveloped for this region. However, five subzones, Globorotalia crassaformis viola, Globorotalia crassaformis hessi, Globigerina calida calida, Globigerina bermudezi, and Globorotalia fimbriata Subzone have been distinguished.

In the paleontological part there are notes on selected planktonic foraminifer species with respect to ranges, distributions, and paleoclimatic values. In the plates there are scanning electron micrographs of the ultrastructures, which show that the ultrastructure of the outer surface of the wall should be used for the systematic position, but ultrastructure peculiarities due to environmental influences also should be considered.

\section{INTRODUCTION}

Quaternary sediments have been recovered from five sites off north-west Africa during Leg 41 of the Deep Sea Drilling Project (Figure 1, Table 1). With respect to water depth, the sites can be grouped into two deepbasin sites, 367 (Cape Verde Basin) and 370 (deep basin off Morocco), two rise-sites, 366 (Sierra Leone Rise) and 368 (Cape Verde Rise), and one slope site, 369 (off Spanish Sahara).

Lithologies of Site 366 are nanno marls and oozes with varying abundances of foraminifers, radiolarians, and diatoms, yellowish brown at the top to dark brown at the base. At Site 368 the color changes from pale yellowish brown to greenish or olive-gray or graygreen. Slope Site 369 recovered only a thin layer of Quaternary grayish orange and greenish gray soft

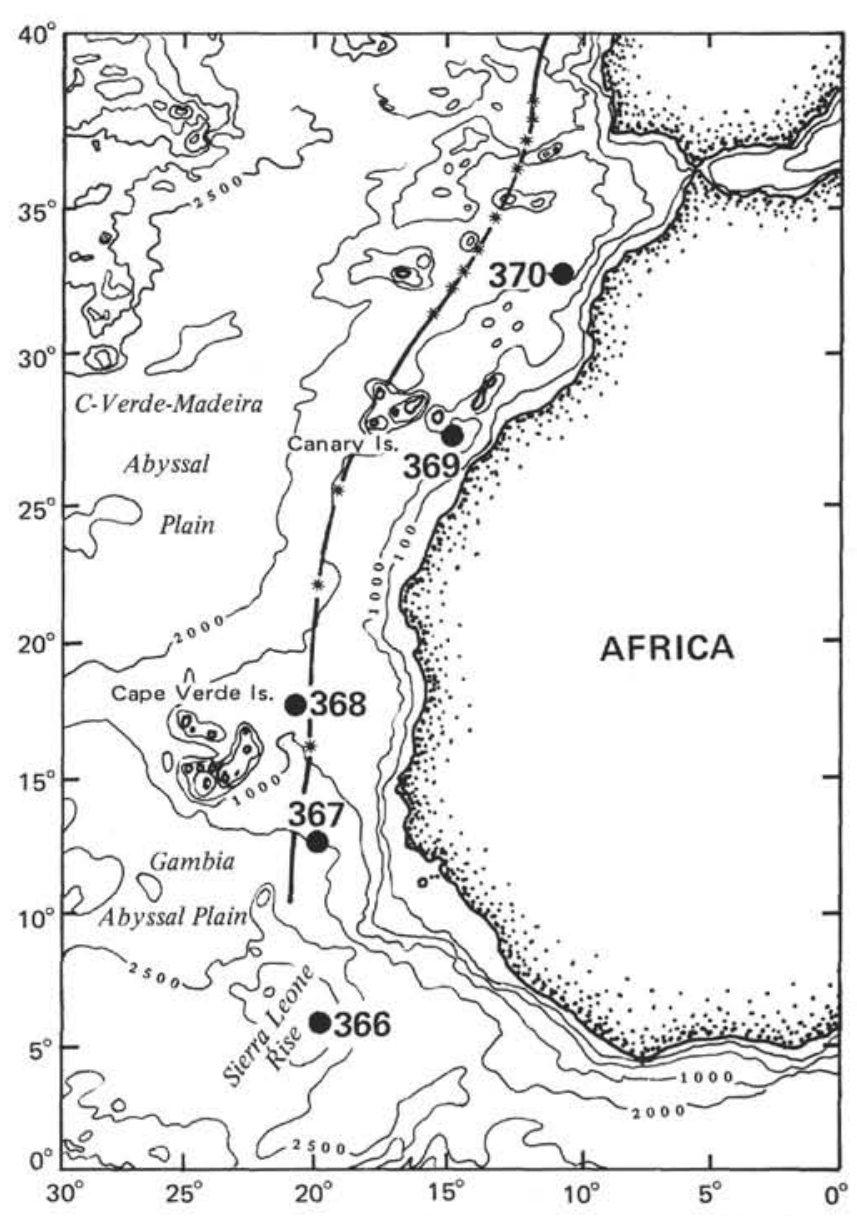

Figure 1. Locations of Leg 41 Sites 366, 367, 368, 369, and 370 .

clayey nanno ooze. Basin Site 367 encountered Pleistocene nanno marls and nanno-bearing silty clays, moderate yellowish brown and dark greenish gray to dark gray. At Site 370 the Quaternary record is yellowish brown clay, squeezed by drilling between sediments of Pliocene age.

In general planktonic foraminifers are abundant and well preserved. In the uppermost layers they are accompanied by calcareous nannoplankton, radiolarians, and diatoms, while in the deeper sections siliceous microfossils are missing. The benthic foraminifers are rare at the rise sites, more common at the slope site, and relatively common at the basin sites. 
TABLE 1

Data on Quaternary of Leg 41 Holes

\begin{tabular}{|c|c|c|c|c|c|c|c|c|}
\hline Hole & $\begin{array}{l}\text { Latitude } \\
\text { (N) }\end{array}$ & $\begin{array}{l}\text { Longitude } \\
\text { (W) }\end{array}$ & $\begin{array}{l}\text { Water } \\
\text { Depth } \\
\text { (m) }\end{array}$ & $\begin{array}{l}\text { Drilled in } \\
\text { Quaternary } \\
\text { (m) }\end{array}$ & $\begin{array}{l}\text { Recovered } \\
\text { (m) }\end{array}$ & Samples & $\begin{array}{c}\text { Age of } \\
\text { Underlying } \\
\text { Sediments }\end{array}$ & $\begin{array}{l}\text { Uncored In- } \\
\text { terval to the } \\
\text { Underlying } \\
\text { Layers (m) }\end{array}$ \\
\hline 366 & $05^{\circ} 40^{\prime} 68^{\prime \prime}$ & $10^{\circ} 51^{\prime} 08^{\prime \prime}$ & 2860 & 14.5 & 12.9 & 21 & See $366 \mathrm{~A}$ & See $366 A$ \\
\hline $366 \mathrm{~A}$ & $05^{\circ} 40^{\prime} 70^{\prime \prime \prime}$ & $19^{\circ} 51^{\prime} 10^{\prime \prime}$ & 2860 & 25.0 & 24.0 & 33 & Pliocene & no \\
\hline 367 & $12^{\circ} 29^{\prime} 21^{\prime \prime}$ & $20^{\circ} 02^{\prime} 83^{\prime \prime}$ & 4748 & 17.5 & 16.9 & 26 & Pliocene & 36.5 \\
\hline 368 & $17^{\circ} 30^{\prime} 43^{\prime \prime}$ & $21^{\circ} 21^{\prime} 23^{\prime \prime}$ & 3367 & 56.5 & 21.8 & 32 & Pliocene & 28.5 \\
\hline 369 & $26^{\circ} 35^{\prime} 55^{\prime \prime}$ & $14^{\circ} 59^{\prime} 96^{\prime \prime}$ & 1760 & 1.3 & 1.3 & 3 & Pliocene & no \\
\hline 370 & $32^{\circ} 50^{\prime} 25^{\prime \prime}$ & $10^{\circ} 46^{\prime} 56^{\prime \prime}$ & 4216 & 8.0 & 6.5 & 12 & Pliocene & 95.0 \\
\hline
\end{tabular}

Their living areas were shallower water depths, so redeposition has occurred.

For planktonic foraminiferal zonation schemes we used Blow (1969) and Bolli and Premoli Silva (1973). For Quaternary stratigraphy the most important holes of Leg 41 are $366 \AA$ and 368 , as the sediments conformably rest on the Globorotalia tosaensis Zone. Quaternary sediment is yellowish brown nanno marls and oozes at the top, but changes to dark brown, greenish gray, or olive-gray at the base. The softness of the sediment permitted intense drilling disturbances.

For this report we studied 116 samples: 75 were taken from Sites 366, Sierra Leone Rise, and 368, Cape Verde Rise. The support by the Deutsche Forschungsgemeinschaft is gratefully acknowledged.

\section{METHODS}

After determination of volume and wet weight, the samples were dried at $60^{\circ} \mathrm{C}$ for 24 hours and weights of the dried samples were recorded. The samples were immersed in water with small amounts of $\mathrm{H}_{2} \mathrm{O}_{2}$ buffered by ammonia and washed through a set of $63 \mu \mathrm{m}$ and 40 $\mu \mathrm{m}$ sieves. Dried residues were weighed, the fraction $>63 \mu \mathrm{m}$ was split using a microsplitter, and the split was sieved into fractions of 63-160, 160-200, 200-315, $315-630,630 \mu \mathrm{m}$. The fractions were weighed. The split contained at least 800 to 1000 specimens of planktonic foraminifers larger than $160 \mu \mathrm{m}$.

Planktonic foraminifer species and specimens in the fractions $>200 \mu \mathrm{m}$ were counted. Other groups of counted particles were broken planktonic foraminifers, benthic foraminifers, radiolarians, carbonaceous and siliceous megafossils, quartz, and other mineral and sediment grains.

\section{MAIN CHARACTERS OF THE PLANKTONIC FORAMINIFER FAUNA}

Due to the geographic position of the sites, the planktonic foraminifer fauna can be attributed to the tropical-subtropical province. Main components are species of the genera Globigerinoides ( $G$. ruber, $G$. trilobus, G. conglobatus), Globorotalia (G. tumida, G. cultrata, G. crassaformis, G. truncatulinoides), Neogloboquadrina ( $N$. dutertrei), and Orbulina (O. universa). The somewhat northerly position of Site 368 is marked by the elevated amounts of Globigerina ( $G$. bulloides, $G$. pachyderma) and the presence of Globorotalia inflata among the dominant species.
In the Quaternary sediments the following species of planktonic foraminifers have been established:

\begin{tabular}{|c|c|}
\hline $\begin{array}{l}\text { Globigerina } \\
\text { G. bulloides }\end{array}$ & $\begin{array}{l}\text { Globigerinella } \\
\text { G. siphonifera }\end{array}$ \\
\hline G. calida calida & \\
\hline G. calida praecalida & Hastigerina \\
\hline G. falconensis & H. pelagica \\
\hline G. megastoma & \\
\hline "G." pachyderma & Orbulina \\
\hline "G." quinqueloba & O. universa \\
\hline $\begin{array}{l}\text { G. rubescens (white and pink } \\
\text { variations) }\end{array}$ & $\begin{array}{l}\text { Sphaeroidinella } \\
\text { Sp. dehiscens }\end{array}$ \\
\hline G. (Beella) digitata digitata & \\
\hline G. (B.) digitata praedigitata & $\begin{array}{l}\text { Pulleniatina } \\
\text { P. obliquiloculata }\end{array}$ \\
\hline Globigerinoides & P. primalis \\
\hline $\begin{array}{l}\text { G. bollii } \\
\text { G. conglobatus }\end{array}$ & P. praecursor \\
\hline G. obliquus obliquus & Globorotalia \\
\hline G. cf. obliquus extremus & G. bermudezi \\
\hline $\begin{array}{l}\text { G. ruber (pink and white } \\
\text { variations) }\end{array}$ & $\begin{array}{l}\text { G. crassaformis crassaformis } \\
\text { G. crassaformis hessi }\end{array}$ \\
\hline G. elongatus & G. crassaformis oceanica \\
\hline G. tenellus & G. crassaformis ronda \\
\hline G. trilobus trilobus & G. crassaformis viola \\
\hline G. trilobus aff. fistulosus & G. cultrata \\
\hline G. trilobus sacculifer & $\begin{array}{l}\text { G. fimbriata } \\
\text { G. hirsuta } \\
\text { G. humerosa } \\
\text { G. inflata }\end{array}$ \\
\hline Globigerinita & G. menardii \\
\hline G. glutinata & G. pseudopima \\
\hline G. uvula & $\begin{array}{l}\text { G. puncticulata } \\
\text { G. scitula }\end{array}$ \\
\hline Candeina & \\
\hline C. nitida & $\begin{array}{l}\text { Globorotaloides } \\
\text { G. hexagonus }\end{array}$ \\
\hline G. tosaensis & \\
\hline G. truncatulinoides & Turborotalita \\
\hline G. tumida tumida & T. humilis \\
\hline G. tumida flexuosa & \\
\hline $\begin{array}{l}\text { G. triangula } \\
\text { G. ungulata }\end{array}$ & $\begin{array}{l}\text { Neogloboquadrina } \\
\text { N. dutertrei }\end{array}$ \\
\hline
\end{tabular}

Distribution of these species is shown on Tables 2 and 3. The majority occurs throughout the Quaternary section, but there are species and subspecies with restricted ranges which are used for subdivision of Quaternary.

\section{PLEISTOCENE-HOLOCENE ZONATION}

The Quaternary section has been treated almost as a single foraminifer faunal zone. Subdivisions mostly result from the changing climate conditions. However, investigations of marine sediment sections permit subdivision by evolutionary trends within planktonic foraminifers (Blow, 1969; Lamb and Beard, 1972; Bolli and Premoli Silva, 1973; and Rögl, 1974). General agreement attributes the Quaternary to the Globo- 
TABLE 2

Quaternary Stratigraphy and Planktonic Foraminifers of the Eastern Atlantic, Deep Sea Drilling Project, Leg 41

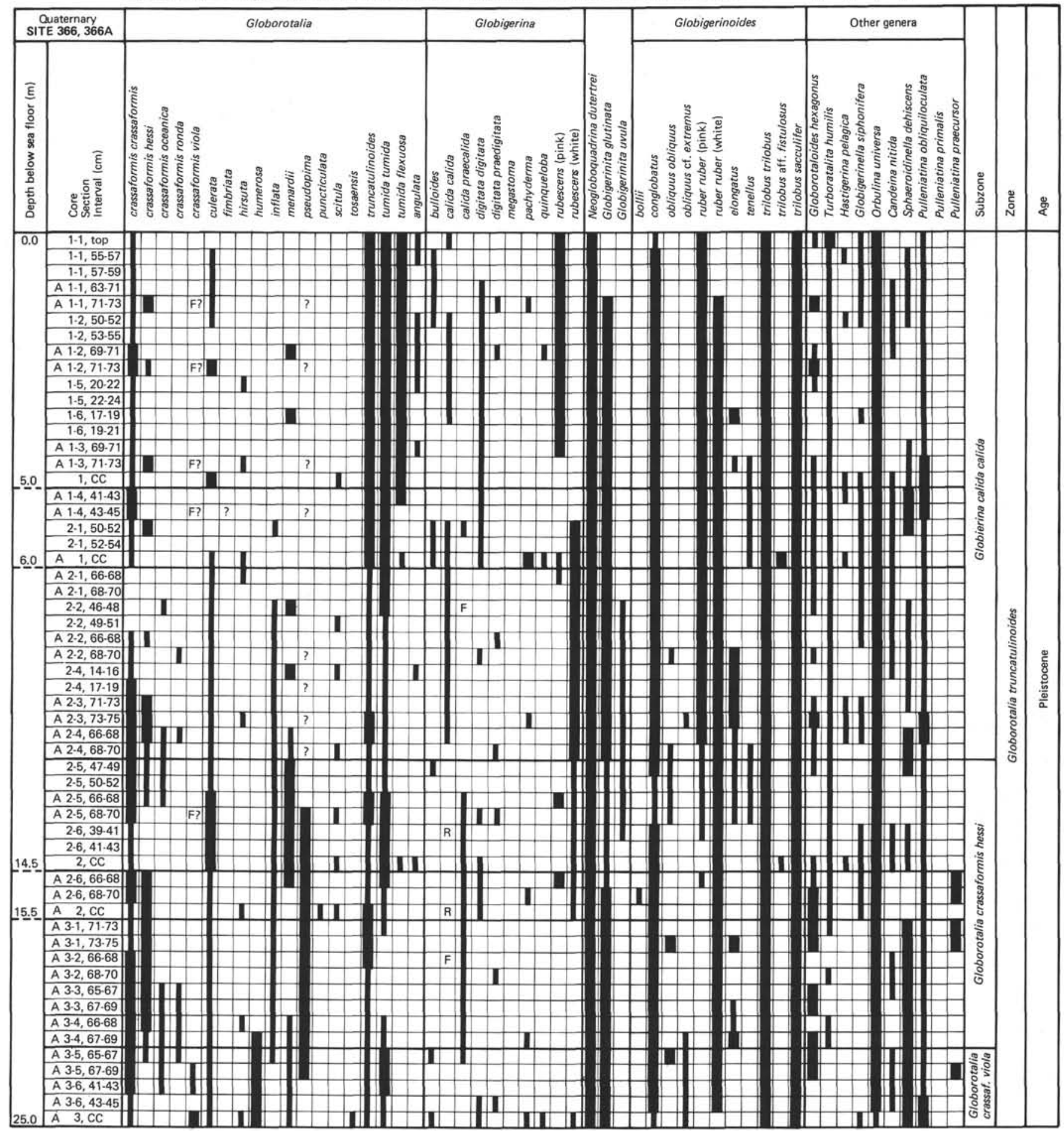

rotalia truncatulinoides Zone, although Blow (1969) divides the Pleistocene/Holocene into independent zones, using a Globorotalia truncatulinoides Partial Range Zone (N22) and an assemblage zone with Globigerina calida calida and Sphaeroidinella dehiscens excavata (N23). Lamb and Beard (1972), however, defined the Globorotalia truncatulinoides Zone as the interval from the extinction horizon of Globoquadrina altispira to the first occurrence of large forms of Globorotalia tumida (restricted?) in the Gulf of Mexico region. Subdivision had been done into three subzones, using Globorotalia tosaensis extinction and first occurrence of Pulleniatina finalis as subzonal boundaries.

Bolli and Premoli Silva (1973) defined the Globorotalia truncatulinoides truncatulinoides Zone by the total range of the zonal marker. They distinguished five subzones: the Globorotalia crassaformis viola Subzone, the Globorotalia hessi Subzone, defined as the interval with the subzonal marker from its first occurrence to 
TABLE 3

Quaternary Stratigraphy and Planktonic Foraminifera of the Eastern Atlantic, Deep Sea Drilling Project, Leg 41

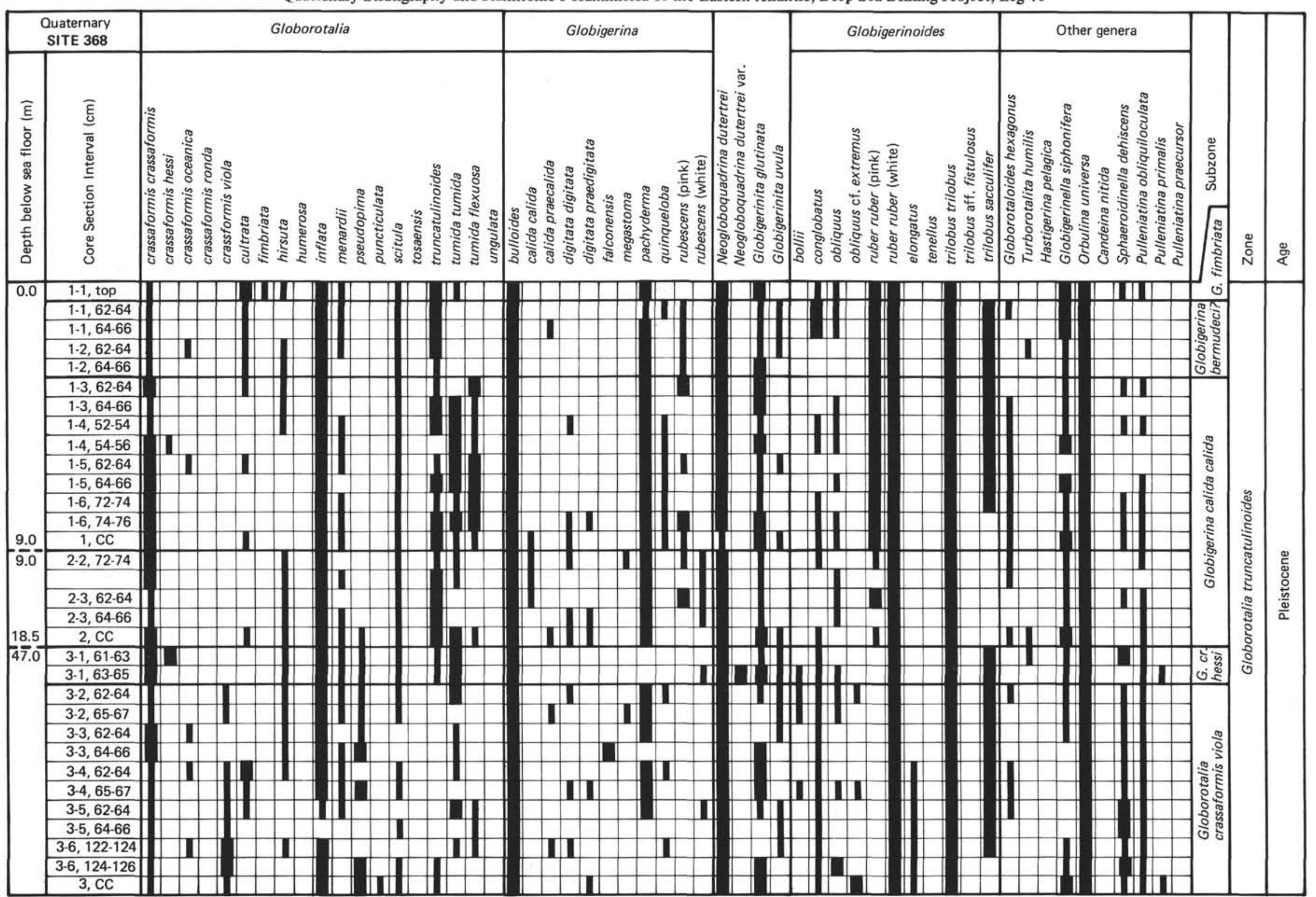


the first appearance of Globigerina calida calida, the Globigerina calida calida Subzone, defined as the interval with the subzonal marker to the extinction of Globorotalia tumida flexuosa, the Globigerina bermudezi Subzone, and the Globorotalia fimbriata Subzone, defined by the range of the subzonal marker. The Globorotalia fimbriata Subzone corresponds to the Holocene, while the other four subzones are placed within the Pleistocene. The first two subzones correspond to the Globorotalia truncatulinoides Zone of Blow (1969), while the later three subzones are equal to Zone N 23. This subzonal scheme has been used by Rögl (1974) for subdividing a very thick section of Quaternary sediments from the Indian Ocean (DSDP Leg 27). We try to follow the zonation of Bolli and Premoli Silva (1973).

\section{REGIONAL STRATIGRAPHY}

On the Sierra Leone Rise (Site 366) Globorotalia truncatulinoides starts at Sample 366A-3, CC, which is at about 24 meters core depth above the Globorotalia tosaensis Zone. As Globorotalia hessi has its first appearance at Section 366-3-4, the underlying section should belong to the Globorotalia crassaformis viola Subzone. The base of the Globigerina calida calida Subzone could not be precisely defined by the first occurrence of index species because of its scattered and atypical distribution in this region. Therefore the upper boundary of the Globorotalia hessi Subzone remains unsure. However, the presence of Globorotalia tumida flexuosa in the uppermost three sections of Core 366-1 together with pink Globigerinoides ruber, Globigerina rubescens, and Globorotaloides hexagonus offer an age for these samples no younger than the Globigerina calida calida Subzone. As a substitute for the index species we used occurrences of pink Globigerinoides ruber and pink Globigerina rubescens as markers for the Globigerina calida calida Subzone. The youngest Quaternary subzones (the Globigerina bermudezi and Globorotalia fimbriata Subzones) have not been detected apparently because of drilling disturbance. The Quaternary sediments here are soft nanno and nanno-foraminifer oozes and marls.

In the Cape Verde Basin (Site 367) deep-water Quaternary turbidites consist of clays, silty clays, and nanno and foraminifer-bearing marls with heterogeneous microfauna and microflora. These Quaternary sediments, 17.5 meters in thickness, are separated from Pliocene by a 36-meter uncored interval. In Core 367-2 Globorotalia crassaformis hessi is present, inferring an age no older than the Globorotalia crassaformis hessi Subzone. In Core 367-1 pink Globigerinoides ruber, Globigerina rubescens together with Globorotalia tumida flexuosa and Globorotaloides hexagonus occur and the age of sediments obviously is within the interval of the Globigerina calida calida Subzone.

The section of the Quaternary foram-bearing nanno marls and oozes on the Cape Verde Rise (Site 368) is 56 meters in thickness and all five subzones occur. Unfortunately the Quaternary/Pliocene boundary is unknown here because Quaternary and Pliocene (the Globorotalia miocenica Zone) are separated by the 28.5meter uncored interval.
Core 368-3, except Section 368-3-1, is attributed to the early Pleistocene Globorotalia crassaformis viola Subzone, represented by Globorotalia inflata, Globorotalia truncatulinoides, Globorotalia crassaformis viola, Globorotalia pseudopima. A mixing with Pliocene sediments cannot be excluded, as Globigerinoides obliquus and Globigerinoides obliquus extremus occur throughout this core.

Sample 368-3-1, 61-63 cm, contains abundant Globorotalia crassaformis hessi and marks the lower boundary of the Globorotalia crassaformis hessi Subzone. The apparent thickness of the subzone is rather significant, about 30 meters, but the upper boundary is difficult to set as Globigerina calida calida is a rare fossil in this region.

The lower boundary of the occurrence of pink Globigerinoides ruber and Globigerina rubescens is in Section 368-2-3. Rare specimens of Globigerina calida calida occurring with Globorotalia tumida flexuosa and Globorotaloides hexagonus suggest the presence of the Globigerina calida calida Subzone, from Section 368-1-3 to Section 368-2-3. Thickness is about 10.5 meters.

The interval between Samples 368-1-1, 62-64 cm, and $368-1-2,62-64 \mathrm{~cm}$, is characterized by the absence of both Globorotalia tumida flexuosa and G. fimbriata. It is quite possible that sediments of this interval belong to the Globigerina bermudezi Subzone in accordance with Bolli and Premoli Silva's definition of this stratigraphic unit.

In the upper portion of Core 368-1, assemblages of planktonic foraminifers include Globorotalia fimbriata, G. truncatulinoides, Globigerinoides ruber (pink and white), Globigerina rubescens (pink), etc. This sample is attributed to the Globorotalia fimbriata Subzone. The preservation of primitive agglutinated foraminifers (thin-walled Rhabdammina, etc.) and the elevated percentage of tropical species confirm the presence of the topmost surface sediments of Holocene age.

On the continental slope off Spanish Sahara (Site $369)$ a thin layer $(1.5 \mathrm{~m})$ of nanno-foraminifer oozes rests unconformably on the early Pliocene sediments (the Globorotalia margaritae evoluta Zone). The presence of Globorotalia truncatulinoides, $G$. inflata, Globigerinoides ruber (pink), Globigerina rubescens (pink), Globigerina calida aff. calida, Globorotalia aff. fimbriata, etc. places these sediments in the Globigerina calida calida Subzone s.l.

Quaternary deep-water nanno-foraminifer-bearing clays of ${ }^{\circ}$ the Morocco Basin are characterized by mixed foraminifer assemblages of different age and paleoenvironment (Site 370), which indicates turbiditic origin of sediments. In the top sample of Core 370-1 cooccurrence of pink specimens of Globigerina rubescens, Globigerinoides ruber, with Globorotalia truncatulinoides places these oozes within the Globigerina calida calida Subzone s.1. In Sample 370-1, CC Globorotalia truncatulinoides, G. crassaformis hessi, etc., are not accompanied by pinkish Globigerinoides and Globigerina, and sediments may belong to the older part of the Quaternary. A large uncored interval $(95 \mathrm{~m})$ separates Quaternary sediments from upper MiocenePliocene turbidites.

The quantity of specimens of Globorotalia inflata, Globigerina bulloides, "G." pachyderma in Quaternary 
sediments of Site 369 and 370 is larger than that in the southern sites.

The data presented lead to conclusion that zonation of Quaternary tropical and subtropical sediments by Bolli and Premoli Silva (1973) for the Caribbean Sea and by Rögl (1974) for the subdivision of the Quaternary sediments of the Timor Trough in the Indian Ocean is also applicable for the Quaternary stratigraphy of the northwest Atlantic. The same subzonal units have been recognized here within the Globorotalia truncatulinoides Zone: Globorotalia crassaformis viola, Globorotalia crassaformis hessi, Globigerina calida calida s. str., and Globigerina bermudezi Subzones (Pleistocene) and the Globorotalia fimbriata Subzone (Holocene).

The uniform succession of foraminifer assemblages in Quaternary sediments of the Caribbean basin, northwest Atlantic, and Timor Trough proves that this subzonal subdivision is based on the evolutionary development of planktonic foraminifers. But the Quaternary zonal and subzonal scheme has many limitations and may be applied only in case of rich microfauna with high diversity. If diversity is not high the application of this stratigraphic scheme faces many difficulties and its precision decreases. Thus, in the late Pliocene-early Pleistocene of the Leg 41 area Globorotalia tosaensis is practically absent. In Quaternary sediments Globorotalia truncatulinoides and G. tumida flexuosa are irregularly distributed; Globigerina calida calida is extremely rare and untypical; Hastigerinella adamsi is missing completely; white specimens of Globigerinoides ruber and Globigerina rubescens display a very gradual transition to the younger pinkish and pink ones; variability of Globorotalia crassaformis viola and $G$. crassaformis hessi makes identification difficult, etc. All these complications permit us to deliniate rather tentative subzonal boundaries.

\section{PLANKTON-BENTHOS RATIO}

The foraminifer plankton-benthos ratio expressed as benthic foraminifers per total foraminifers is a good tool to check the water depths on the slopes. In deepsea sites far from the continental margin increased amounts of benthic foraminifers mark either redepositional effects or, if the increase is spread over longer time intervals, it may be caused by uplifts or by differential dissolution. To decide the main influence, composition of the benthic foraminifers and state of preservation of planktonic and benthonic foraminifers can be checked.

In the Quaternary samples of Site 366, the benthic foraminifers are fairly constant around $1 \%$ of total forams, which is in agreement with the water depth of 2860 meters and location on the rise. Similar values occur for Site 368 (Cape Verde Rise), where the values range between $1 \%$ and $2 \%$. The slope Site 369 shows somewhat higher values (around 3\%), due to the lower water depth. At Site 367 (Cape Verde Basin) there are generally elevated amounts of benthic foraminifers up to $50 \%$, and at Site 370 (deep basin off Spanish Sahara) they reach about $10 \%$. The diversity of the benthic foraminifers is high. There are species of the genera Melonis, Bulimina, Bolivina, Lenticulina, all from shallower water, therefore redeposition has occurred.

\section{PALEONTOLOGICAL PART}

In the following section we present ranges, distributions, and paleoclimatic values for selected species. For some species we also include ranges in prequaternary sediments. The figured specimens as well as the negatives of the SEM photographs are deposited in the Geological Paleontological Institute of the Kiel University.

\section{Genus GLOBIGERINA d'Orbigny, 1826}

\section{Globigerina bulloides d'Orbigny}

(Plate 1, Figures 8-10)

Globigerina bulloides d'Orbigny-Banner and Blow, 1960, p. 3-4, pl. 1, fig. la-c, lectotype).

We have not distinguished among the various subspecies. Globigerina bulloides occurs scattered and in minor abundances since the Globorotalia acostaensis Zone of Site 366; more commonly, we encountered it in the middle part of the Globorotalia margaritae evoluta Zone. In Quaternary sediments of Site 366 it is quite rare.

At Site 367 it is common from Section $367-4-2$ (mixed fauna no older than Pliocene). At Site 368 Globigerina bulloides is common to abundant from Section 368-6-3, attributed to the Globorotalia margaritae evoluta Zone, up to Recent. Its range at Site 369 is similar to that at Site 366 , but it has higher abundance. There are some specimens from the beginning of the Praeorbulina glomerosa Zone, which are similar to the outline of Globigerina bulloides. The samples of Site 370 contain Globigerina bulloides from 370-2, CC, (mixed fauna no older than late Miocene) to Section 370-1-1 (Globigerina calida calida Subzone). Globigerina bulloides is considered as a temperate to cool-water inhabitant.

\section{Globigerina calida Parker \\ (Plate 1, Figures 5-7)}

Globigerina calida Parker, 1962, p. 221, pl. 1, fig. 9-11.

Globigerina calida calida Parker-Blow, p. 317, pl. 13, fig. 9,10.

Range according to Bolli and Premoli Silva (1973) from ${ }^{\circ}$ the base of the Globigerina calida calida Subzone to Recent.

Interpreted according to Blow (1969), this species is very rare. There are intergrades to Globigerina calida praecalida Blow as well as to juvenile forms of Globigerinella siphonifera. Occurrence of $G$. calida calida: Site 366 from 366A-2-4 to 366-1-1 (top), rare; Site 368: from $368-2-3$ to $368-1$, CC (rare). Globigerina calida praecalida has a wider range. At Site 366 it starts in the Globorotalia crassaformis viola Subzone, but has few and scattered occurrences. At Site 368 its first occurrence is in Section 368-7-2 (Globorotalia plesiotumida Zone), while at Site 369 there are only isolated records from 369A-1-3 (technically mixed faunas) and $369-1-1,112-114 \mathrm{~cm}$, (Holocene).

\section{Globigerina? quinqueloba Natland}

(Plate 2, Figures 10-12)

Globigerina quinqueloba Natland 1938, p. 149, pl. 6, fig. 7 .

Globigerina quinqueloba Natland-Parker, 1962, p. 225, pl. 2, fig. 716.

According to Blow $(1969$, p. 373$)$ this species should be placed into the genus Turborotalita. But as there are distinct spine basis with hollows, visible on Plate 2, Figure 10b, the species has to be attributed to the Globigerinids. By its general outline it is isolated from the other species of Globigerina (see also Rögl and Bolli, 1973, p. 564).

We regard this species as a distinct cool-water indicator. Its mean size is around 160

$\mu \mathrm{m}$ in diameter, so quantitative distribution cannot be determined. In Leg 41 sites it ranges at Site 366, from 366A-12-6 (Globorotalia plesiotumida Zone) to topmost samples; Site 367, it is present in 367-1, CC (Pleistocene); Site 368, it starts at 368-8-1 (Globorotalia acostaensis Zone); Site 369, in the mixed sample 369A-1, CC; and Site 370 , its first occurrence is in Sample 370-2, CC (not older than late Miocene).

Its Quaternary record is rare and scattered throughout at Site 366 and somewhat more frequent at Site 368. 
"Globigerina" pachyderma-incompta group (Plate 6, Figures 10-12)

Globigerina pachyderma (Ehrenberg)-Parker, 1962, p. 224, pl. 1, fig. 1-3.

Globigerina borealis Brady-Banner and Blow, 1960, p. 4, pl. 3, fig. $4 \mathrm{a}-\mathrm{c}$.

Globigerina incompta Cifelli, 1961, p. 84, pl. 4, fig. 1-7.

There are considerable difficulties in the exact distinction within this species group. Additionally there are intergrades to Neogloboquadrina dutertrei, "Globigerina" eggeri and "Globorotalia (Turborotalia)" acostaensis pseudopima Blow.

The generic position of this group is in discussion. Rögl and Bolli (1973, p. 571) as well as Srinivasan and Kennett (1976, p. 334-335) attribute pachyderma and incompta to Neogloboquadrina with respect to the ultrastructure and the intergrades to the $N$. dutertrei plexus. However, Bé (1967) did not exclude a spinosity of the juvenile forms, and Cifelli (1973) pointed to the lack of umbilical plates, not good criteria for the separation from Globigerina.

Range according to Blow (1969, p. 316) for $G$. borealis: from within Zones N. 20 to N. 23, which is nearly the same as for $G$. (T.) pseudopima.

Left-coiling specimens are very rare. This group is nevertheless considered as the most important cool-water indicator.

Occurrence in Leg 41 sites: Site 366, from 366A-5-4 (Globorotalia exilis Subzone) to 366A-1-1 ( $G$. calida calida Subzone), few and scattered; Site 367 , from 367-3, CC (mixed fauna, no older than Pliocene) to 367-1-1; Site 368, common from 369-3-5 (Globorotalia crassaformis viola Subzone) to 369-1-1 (Holocene); Site 369, from 1-2 (Pleistocene) to 1-1 (Holocene); Site 370, from 370-1, CC (mixed assemblage, Pleistocene) to 370-1-1 (Pleistocene).

We used the term Globigerina pachyderma-imcompta for forms with a nearly closed umbilicus, with 4 to $4-1 / 2$ chambers in the last whorl, and a distinct apertural lip. The coiling is predominantly to the right, but in some samples of the northerly sites left-coiling specimens have been encountered as well. In general the specimens are distinctly smaller than the representatives of the quite similar Neogloboquadrina plexus.

\section{Globigerina rubescens Hofker}

(Plate 1, Figures 11-13)

Globigerina rubescens-Hofker, 1956, p. 234, pl. 35, fig. 18-21. Globigerina rubescens Hofker-Parker, 1962, p. 226, pl. 2, fig. 17 18.

Range according to Blow (1969, p. 322) from Zone N. 20 to Recent. Parker (1962) reported, that white colored specimens prefer the cooler latitudes of the distribution area of the species, which is found north of $35^{\circ} \mathrm{S}$ in the South Pacific.

Occurrence in Leg 41 sites: Site 366, few from 366A-6, CC (higher part of Globorotalia margaritae evoluta Zone) to $366 \mathrm{~A}-1-1$, pink colored specimens in 366A-2-1, Globigerina calida calida Subzone; Site 367 , few pink colored specimens in 367-1, CC (mixed fauna, Pleistocene); Site 368, few from 368-3-1 (Pleistocene) to 368-1-1 (Holocene), pink since 368-2-3 (Globigerina calida calida Subzone): Site 369, none; Site 370, 370-1-1 (top) (Globigerina calida calida Subzone), pink, few.

Remarks: The mean diameter of this species is below $200 \mu \mathrm{m}$, so in the statistical counts it is often omitted.

\section{Globigerina (Beella) digitata Brady}

(Plate 1, Figures 14-16)

Globorotalia (Beella) digitata (Brady)-Banner and Blow, 1960, p. 26-28, text-fig. 11a-c (lectotype)

Range throughout Quaternary of the Sites 366 and 368 but in scattered occurrences.

Remarks: Globigerina (Beella) digitata digitata in the sense of Blow $(1959$, p. 323$)$ is very rare in our material and recorded more constantly in the samples of the Globigerina calida calida Subzone, whereas forms, which belong to the $G$. praedigitata-type are somewhat more frequent throughout the Quaternary. The occurrence of $G$. digitata digitata seems to be controlled by tropical conditions, but the scarcity reduces its climatologic value.

\section{Genus GLOBIGERINELLA Cushman, 1927}

Globigerinella siphonifera (d'Orbigny)

$$
\text { (Plate 1, Figures 1-4) }
$$

Globigerina siphonifera d’Orbigny, 1839, p. 83, pl. 4, fig. 15-18.
Hastigerina (Hastigerina) siphonifera (d'Orbigny) - Banner and Blow, 1960 , p. 22-23, text-fig. 2a-c (lectotype), 3a-b.

Globigerinella aequilateralis (Brady)-Saito, Thompson, and Breger, 1976 , p. $281-282$, pl. 3 , fig. 1,2 , pl. 6 , fig. 7 , pl. 8 , fig. 3,8 .

Remarks: In the generic attribution of this species we follow the concept given by Saito et al. (1976), but we believe that the variability of the species is so wide, that the figured holotype of d'Orbigny and the lectotype of Banner and Blow belong to the same species. Therefore the species name siphonifera has priority.

Occurrence in Leg 41 sites: Site 366, from 366A-12, CC (Globorotalia plesiotumida Zone to Recent, scattered occurrences, common in parts of Globorotalia margaritae margaritae Zone as well as in the later parts of Pliocene; Site 367, rare in Core 367-4-2 (Pliocene) and from 367-1-4 to 367-1-1 (Pleistocene, no older than Globigerina calida calida Zone; Site 368, common in Core 368-6 (uppermost Globorotalia plesiotumida Zone and Globorotalia margaritae margaritae Zone), few and scattered in Pliocene and early Pleistocene, more common in Core 368-1, attributed to the undifferentiated Globorotalia hessi/Globigerina calida calida zones and Holocene; Site 369. very rare occurrences since Globorotalia peripheroacuta Zone (? contaminated) more common since Core 369-4 (Globorotalia margaritae margaritae Zone and Globorotalia margaritae evoluta Zone); Site 370, few in Samples 370-2-1 (Globorotalia margaritae margaritae Zone), and 370-1-4, 370-1-2 (Pleistocene).

Remarks: Besides the planispiral forms there are all intergrades to trochospirally coiled specimens, which are nearly in the vicinity of Globigerina calida praecalida. In late Miocene and early Pliocene there have been met more involute specimens, which may be attributed to the subspecies involuta.

Globigerinella siphonifera is treated as a tropical species.

\section{Genus GLOBIGERINOIDES Cushman, 1927}

\section{Globigerinoides conglobatus (Brady)}

(Plate 4, Figures 4-6)

Globigerina conglobata Brady, 1879-Banner and Blow, 1960, p. 6-7, pl. 4, fig. 4a-c, lectotype.

Globigerinoides conglobatus is a very thick-walled species, which is treated as more resistant against dissolution than the other species of Globigerinoides. During the late Quaternary it occurs in the tropicalsubtropical belt, characteristic for more a deep water habitat.

In Leg 41 sites the species is common in nearly all samples from Site 366 , while its abundance is few and it is scattered in the samples of the other sites.

\section{Globigerinoides elongatus (d'Orbigny)}

(Plate 3, Figures 7-9)

Globigerina elongata d'Orbigny, 1826, p. 277 , list no. 4.

Globigerina elongata d'Orbigny-Banner and Blow, 1960, p. 12-13, pl. 3, fig. 10a-c (lectotype).

This species is distinguished from elongated Globigerinoides ruber in having only one secondary aperture per chamber on the spiral side. Its occurrence in Quaternary is generally rare and restricted to some samples: Site 366A-1, CC (Globigerina calida calida Subzone); Site $368,368-3-4$ to $368-3$, CC (early Pleistocene); Site $369,369-1-1$ (Globigerina calida calida Subzone).

\section{Globigerinoides ruber (d'Orbigny)}

(Plate 3, Figures 1-6)

Globigerina rubra d'Orbigny, 1839, p. 82, pl. ๑, fig. 12-14.

Globigerinoides ruber (d'Orbigny)-Parker, 1962, p. 230-231, pl. 3 , fig. $11,12,14$, pl. 4, fig. 1-3, 5-10.

The Quaternary record of Globigerinoides ruber is given by its warm water preference, but with considerable tolerance to cooler regions. The pink colored variety, known before only from the Atlantic region, has been used by us as a marker for the late Pleistocene zones, starting with the Globigerina calida calida Zone. Other varieties with a short coiling axis and another with a long coiling axis, resulting in a high spired form, have been distinguished. The last mentioned differs from Globigerinoides elongatus in the position of the main aperture, being strictly symmetrical over the intercameral suture between the penultimate and antepenultimate chambers, while in the very similar $G$. elongatus the aperture opens asymmetrically to the peripheral part of the penultimate chamber, and in number of secondary apertures per chamber. There are however some specimens, which have two secondary apertures on the spiral side of each chamber and an asymmetrical main aperture, thus intergrading to $G$. elongatus. 
Occurrence in Leg 41 sites: Abundant to common in all Quaternary samples and sites.

\section{Globigerinoides tenellus Parker (Plate 4, Figures 1-3)}

Globigerinoides tenellus Parker, 1958, pl. 6, fig. 7-11.

This small species is very similar to Globigerina rubescens, but differing by the supplementary aperture on the spiral side. Pink colored specimens have been recorded as well.

Its occurrence in Leg 41 sites is restricted to the Quaternary of Site 366 , where it occurred in minor abundances in the Globorotalia crassaformis hessi and Globigerina calida calida subzones.

\section{Genus SPHAEROIDINELLA Cushman, 1927}

Sphaeroidinella dehiscens (Parker and Jones)

Sphaeroidinella dehiscens (Parker and Jones) 1865, Bolli, Loeblich and Tappan, 1957, p. 32, pl. 6, fig. 1,3,5.

Sphaeroidina bulloides d'Orbigny var. dehiscens Parker and Jones, 1865; Banner and Blow, 1960, p. 35, pl. 7, fig. 3a,b (lectotype).

Occurrence in Leg 41 sites: Site 366, from 366-6, CC (Globorotalia margaritae evoluta Subzone) to Recent, common until early Pleistocene thereafter scattered to Recent; Site 367, from 367-4, CC (mixed fauna no older than Pliocene) to 367-1-1: Site 368, from 368-4. 5 (Globorotalia margaritae evoluta Zone) to 368-1-1 (Holocene), few and scattered; Site 369, in 369-1-1 (Holocene); Site 370, in 1-1 (mixed fauna, Quaternary).

According to Hays et al. (1969) the species increases greatly in abundance within the Mammouth Reversal event (3.0 m.y.B.P.) in tropical cores (see also Bandy et al., 1971).

Kennett (1973, p. 585) reported, that Sph. dehiscens in cooler provinces occurs later than the first occurrence of Globorotalia margaritae margaritae, so that its range varies between different water masses.

\section{Genus CANDEINA d'Orbigny, 1839}

\section{Candeina nitida d'Orbigny}

(Plate 2, Figures 1-3)

Candeina nitida d'Orbigny, 1839-Bolli, Loeblich, and Tappan, 1957, p. 35 , pl. 6 , fig. $10 \mathrm{a}-11$.

Occurrence in Leg 41 sites: Site 366, 366A-12, CC (Globorotalia plesiotumida Zone) to Recent, almost few or rare, except some samples in Pliocene, during Quaternary scattered; Site 369, rare since $369-4$, CC (Globorotalia margaritae margaritae Zone) to 369-2, CC (Globorotalia margaritae evoluta Zone).

Remarks: Candeina nitida is a tropical species.

\section{Genus GLOBIGERINITA Brönnimann, 1951}

Globigerinita glutinata (Egger)

(Plate 2, Figures 4-6)

Globigerina glutinata Egger, 1893, p. 371, pl. 13, fig. 19-21.

Globigerinita glutinata (Egger)-Parker, 1962, p. 246-249, pl. 9, fig. 1-16.

In taxonomy we follow Parker (1962).

Occurrence in Leg 41 sites: Site 366, scattered and rare since middle Miocene, somewhat more common in middle Pliocene, common in Quaternary; Site 367, very rare in 367-4-2 (Pliocene), 3673-1 (Pleistocene), 367-1, CC (Pleistocene); Site 368, few to common in Pleistocene, common in Holocene, rare in late Miocene, few in Pliocene; Site 369 , scattered and few since early Miocene, common in early Pliocene and Pleistocene; Site 370, common in Pleistocene (Core 370-1).

Remarks: Globigerinita glutinata becomes larger in size during Pleistocene, a bulla is often not present. This species is treated as belonging to the cool-temperate group.

\section{Globigerinita uvula (Ehrenberg) \\ (Plate 2, Figures 7-9)}

Pylodexia uvula Ehrenberg, 1861, p. 276,277,308.

Globigerinita uvula (Ehrenberg)-Parker, 1962, p. 252-253, pl. 8, fig. 14-26.

This very small species has been recorded as rare in Pliocene and in some Pleistocene samples of Site 366. At Site 368 there are more samples containing this species, but the abundances are few.
Remarks: Banner and Blow (1960) and Parker (1962) discussed the relationships between $G$. uvula and the Globigerina bradyi Wiesner. Further investigations may confirm possible synonymies.

Globigerinita uvula is adjusted to cool water conditions, especially the high trochospiral forms.

\section{Turborotalita humilis (Brady)}

(Plate 2, Figures 13-15)

Truncatulina humilis Brady, 1884, p. 665, pl. 94, fig. 7.

Turborotalita humilis (Brady)-Blow, 1969, p. 373.

Remarks: This small species has been recorded in most Quaternary samples of Site 366 , but is very rare in Globorotalia crassaformis viola Subzone. In Site 368 it is restricted to the uppermost two samples (Sections 368-1-1 and 368-1-2), and 368-2, $\mathrm{CC}$, attributed to the Pleistocene, while in the older sections there are only forms which are similar to G. quinqueloba. At Sites 369 and 370 we have no record of this species. Affinities and possible transitions to $G$. quinqueloba are suggested by reduction of the bulla-like extensions of the last chamber, by reduced wall thickness, and by reduced number of chambers in the last whorl. But Globigerina quinqueloba is spinose, while we have no record of spinosity for Turborotalia. Further investigations on these tiny specimens, being less than $125 \mu \mathrm{m}$ in diameter, are necessary. The species prefers the warmer regions.

\section{Genus GLOBOROTALOIDES Bolli, 1957}

Globorotaloides hexagonus (Natland) (Plate 4, Figures 7-9)

Globigerina hexagona Natland, 1938, p. 149, pl. 7, fig. 1a-c.

This species has its extinction in the last interglacial in the Atlantic province. We encountered it only in the samples of Sites 366 and 368. Its more common abundance in the earlier parts of the Pleistocene and generally higher frequence in Site 366 demonstrate its preference for tropical environments. At Sites 369 and 370 we have no record of this species.

Genus NEOGLOBOQUADRINA Bandy, Frerichs and Vincent, 1967

\section{Neogloboquadrina dutertrei (d'Orbigny) s.l.} (Plate 8, Figures 1-7)

Globigerina dutertrei d'Orbigny-Banner and Blow, 1960, p. 11, pl. 2, fig. 1a-c (lectotype).

There are considerable controversies among investigators in the taxonomic treatment of "Globigerina" dutertrei d'Orbigny, as recently shown and discussed by Srinivasan and Kennett (1976). In our material we encountered all the different species or variations, but the limited time for this initial report could not handle them statistically.

At Site 369 Section 369-1-1 there are common forms with 5 to 4 chambers in the last whorl, without umbilical flaps, which are comparable to $N$. dutertrei blowi Rögl and Bolli as well as to intergrades to "G." pachyderma-incompta.

The first occurrence of umbilical flaps has been recorded from Section 366-3-6 attributed to the early Pleistocene Globorotalia crassaformis viola Subzone. Coiling ratio is at nearly $100 \%$ to the right in all Quaternary samples. There are several lineages observable. The number of chambers in the last whorl increases in younger sediments from 4 to 7 in the Recent. The width of the umbilicus is more open in tropicical areas and the number of chambers with flaps increases in Recent sediments. Forms with apertural rims are more common in early Pleistocene, with the height of the spira being largest during the Globorotalia crassaformis hessi Subzone. Thickness of the wall and the greatest test diameter vary among the samples, with position of the aperture changing from umbilical-extraumbilical to umbilical.

Bandy et al. (1967) included in Neogloboquadrina specimens with and without toothlike umbilical flaps. They agreed the choice of the lectotype by Banner and Blow (1960), who selected a specimen with unclear umbilical features. Parker (1962), as well as Zobel (1968), have shown gradations between several extreme variants and referred these forms to a single species.

Rögl and Bolli (1973) included to Neogloboquadrina the $N$. dutertrei dutertrei, $N$. dutertrei blowi, $N$. dutertrei pseudopima, and $N$. pachyderma pachyderma, $N$. pachyderma incompta, using the ultrastructure of the outer test wall as a deciding criterion. Srinivasan and Kennett (1976) treat the whole group as being part of two 
evolutionary bioseries, linked by intermediate forms, which are the result of interbreeding of adjacent populations not geographically isolated.

Poore and Berggren (1975), however, prefer for biostratigraphic studies to regard all these taxa as paleontologic species.

\section{"Globorotalia" aff. pseudopima Blow}

(Plate 8, Figures 8,9)

Specimens mainly of early Pleistocene age occur with 4 to 5 chambers in the last whorl, fairly narrow umbilicus, and a globorotaliid aperture, bordered by a thin apertural rim. The size of the test is almost small and thin shelled. We do not believe that they are juvenile stages of the Neogloboquadrina dutertrei plexus, as the last whorl shows sudden increased chamber diameters, which cannot be detected in the big tests of adult specimens of Neogloboquadrina dutertrei. The generic attribution is open, as there are given both globorotaliid (apertural characters) and neogloboquadrine features (test ultrastructure).

\section{Genus GLOBOROTALIA Cushman, 1927}

\section{Globorotalia bermudezi Rögl and Bolli}

(Plate 4, Figures 13-15)

Globorotalia bermudezi Rögl and Bolli, 1973, p. 567-568, pl. 6, fig. 16-20, pl. 16, fig. 1-3, text-fig. 6a-c.

Remarks: This small species is quite similar to Globorotalia scitula. It differs by its open umbilicus and the dorsally radially elongate chambers. In our material it reaches only in rare cases diameters larger than $160 \mu \mathrm{m}$. We encountered a few specimens in all Quaternary samples of Site 366, with higher abundances in Sections $366 \mathrm{~A}-2-4$ and $366 \mathrm{~A}-2-5$ attributed to around the boundary Globorotalia crassaformis hessi/Globigerina calida calida subzones. At Site 367 we have no record. The samples of Site 368 contain generally fewer specimens, with maximum abundances in Section 368-1-3, the same stratigraphical interval as the maximum of 366A. At Sites 369 and 370 only single specimens occur. Coiling mode is predominantly to the right. The first occurrence of $G$. bermudezi in our samples is in the Globorotalia crassaformis viola Subzone, where there are specimens with very small umbilicus and stronger elevated umbilical sides. All our Pliocene samples contain no Globorotalia bermudezi. Therefore it may be treated as an additional index marker for the Quaternary. Its climatologic range is believed to be tropical to subtropical.

Globorotalia crassaformis crassaformis (Galloway and Wissler) (Plate 6, Figures 1-3; Plate 7, Figures 5-7)

Globigerina crassaformis Galloway and Wissler, 1927, p. 41, pl. 7, fig. 12a-c.

Globorotalia crassaformis crassaformis (Galloway and

Wissler)-Rögl, 1974, p. 749, fig. 4, no. 1-6, pl. 3, fig. 1-5.

Specimens attributed to this species are most common in the earlier parts of Pleistocene at Site 366, up to the earlier parts of Globigerina calida calida Subzone. In the later parts of that subzone its occurrence is only few to rare. At Site 368 its main distribution is just in the Globigerina calida calida Subzone. We encountered dominantly left-coiling specimens. There are intergrades to Globorotalia crassaformis hessi throughout in the samples from Globorotalia crassaformis hessi Subzone and the younger subzones.

\section{Globorotalia crassaformis hessi Bolli and Premoli Silva} (Plate 6, Figures 4-6)

Globorotalia crassaformis Bolli, 1970, p. 580-581, pl 4, fig. 13-16. Globorotalia crassaformis (Galloway and Wissler) - Lamb and Beard, 1972, pl. 21, fig. 1-8. Globorotalia hessi-Bolli and Premoli Silva, 1973, p. 476-477. Globorotalia crassaformis hessi Bolli and Premoli Silva-Rögl, 1974, p. 752 , fig. 4 , no. $16-21$, pl. 4 , fig. 8-19.

There is a fairly good record of this subspecies at Site 366, Sample $366 \mathrm{~A}-3-5,65-67 \mathrm{~cm}$, while its occurrence at Site 368 is scattered. The specimens with most pronounced subspecies characters described by Rögl (1974) have been encountered in the later parts of the Globigerina calida calida Subzone. Coiling is predominantly to the left.

\section{Globorotalia crassaformis ronda Blow}

(Plate 6, Figures 7-9)

Globorotalia (T.) crassaformis ronda-Blow, 1959, p. 388-390, pl. 4. fig. 4-6, pl. 37, fig. 6-9.
Globorotalia crassaformis ronda Blow-Rögl, 1974, p. 749, fig. 4, No. 13-15, pl. 3, fig. 7-18.

Globorotalia crassaformis ronda is rare to few in the earlier parts of Quaternary sediments from Site 366 , single specimens occur in the lower Globigerina calida calida Subzone.

\section{Globorotalia crassaformis viola Blow}

(Plate 6, Figures 10-12)

Globorotalia (Globorotalia) crassula viola-Blow 1969, p. 397-398, pl. 5, fig. 4-9.

Globorotalia crassaformis viola Blow-Bolli, 1970, p. 580, pl. 3, fig. 1-3.

In the Quaternary this subspecies becomes extinct with the top of the subzone of its name. We encountered it with decreasing abundances since the Pliocene. Specimens with a distinct keel on all chambers are rare. Rounded peripheries on the earlier chambers of the last whorl are more common. This features has been used to accompany the subspecies to the Globorotalia crassaformis group.

\section{Globorotalia crassaformis ssp.}

(Plate 7, Figures 3, 4)

In the youngest Quaternary samples from Hole 366A (down to $366 \mathrm{~A}-2, \mathrm{CC})$ attributed to the Globigerina calida calida Subzone, we observed a form which differs from Globorotalia crassaformis crassaformis in having a thin-walled test, very open umbilicus, and sharpened, keeled periphery throughout the last whorl. These specimens are quite similar to the figures given by Lamb and Beard (1972) as Globorotalia crassacrotonensis from the Pliocene, as well as to the figures given by Rögl (1974) as Globorotalia aff. crotonensis from the Pleistocene.

Globorotalia crotonensis Conato and Follador is more biconvex. Globorotalia hirsuta aemiliana Colalongo and Sartoni (1967, textfig. $2 b$, pl. 31 , fig. $2 b$, pl. 30 , fig. $4 b$, fide Catalogue of Foraminifera) has a quite similar peripheral outline, but contains only $3-1 / 2$ to 4 chambers in the last whorl and has a more closed umbilicus. The same is given in Globorotalia crassacrotonensis Conato and Follador. Stainforth et al. (1975) assigned the latter species to Globorotalia crassaformis plexus. In our opinion there are affinities to Globorotalia crassaformis hessi, without the thick secondary calcite layer as well as to Globorotalia crassaformis viola with a planiconvex peripheral outline and spirally more elongate chambers. Though it may be an additional variant of the highly variable Globorotalia crassaformis plexus we point to the quite similar stratigraphic occurrence in the tropical Atlantic and in the Timor Trough (Rögl, 1974).

\section{Globorotalia cultrata (d'Orbigny)}

(Plate 5, Figures 2-4)

Rotalina cultrata d'Orbigny, 1839-Banner and Blow, 1960, p. 34, pl. 6 , fig. la-c (neotype).

Remarks: This species is flat, biconvex with spira opening slowly and very regularly. It is differentiated from Globorotalia menardii by its nearly symmetrical biconvexity, while in $G$. menardii the umbilical side is distinctly higher than the spiral side. Coiling in Quaternary is only sinistral.

Occurrence in Leg 41 sites: 366A-14-2 (Globorotalia acostaensis Zone) to 9-5 (near base of Globorotalia margaritae evoluta-zone) and 5-3 (Globorotalia exilis Subzone) to 1-2 (Globigerina calida calida Subzone); $367-2$, CC, to $1-1$ (mixed faunas, Pleistocene); $368-6$, CC, to 6-1 (Globorotalia margeritae evoluta Zone) and 3-5 (Globorotalia crassaformis viola Subzone) to 1-1 (Recent); 369-none; 370-none.

\section{Globorotalia fimbriata (Brady) (Plate 5, Figure 1)}

Pulvinulina menardii (d'Orbigny) var. fimbriata Brady, 1884-Banner and Blow, 1960, p. 25, pl. 5, fig. 2a,b (lectotype).

Rare specimens occur in Samples 368-1-1 and 366A-1-4, 63-65 cm, the latter being contamination by drilling. The species is restricted to Holocene (fide Rögl and Bolli, 1973). Our specimens are not very typical, as the keel is only slightly spinose.

\section{Globorotalia inflata (d'Orbigny)}

(Plate 7, Figures 11-13)

Globigerina inflata d'Orbigny, 1839, p. 134, pl. 2, fig. 7-9.

Globigerina inflata d'Orbigny-Banner and Blow, 1967, p. 144-146, pl. 4, fig. 1a-c (lectotype).

This species has been noted as few or rare in the lower half of the Quaternary sediment section of the tropical Site 366, while it is absent 
in the higher parts, belonging to the Globigerina calida calida Subzone. In the northern sites it is more numerous, becoming abundant to dominant in samples of Site 368. In accordance with Be (1960) we treat $G$. inflata as belonging to the temperate species with significant preferences for high nutrient concentrations, relatively low temperatures, and high salinities of the surface waters.

\section{Globorotalia scitula (Brady)}

(Plate 4, Figures 10-12)

Pulvimulina scitula Brady, 1882-Banner and Blow, 1960, p. 27-29, pl. 5, fig. 5a-c.

This species is generally small, it had been recorded in rare and scattered occurrences during all Quaternary subzones of Site 366, in sample 366-3,CC there are forms with diameters up to $350 \mu \mathrm{m}$. At Site 368 there are also few abundances of the species, but the distribution is not as scattered and the sizes are generally larger. At Site 369 Globorotalia scitula is few in the Quaternary samples.

The distribution pattern suggest that the species belongs to a more cool tolerant group.

\section{Globorotalia triangula Theyer}

(Plate 7, Figures 8-10)

Globorotalia inflata triangula Theyer, 1973, p. 200-201, pl. 1, fig. 1-7.

This species is phenotypical transitional between Pulleniatina obliquiloculata and Globorotalia inflata. From Pulleniatina it differs by its clearly trochospiral coiling mode, from Globorotalia inflata by its subacute periphery. The apertural face is similar to Globorotalia crassaformis plexus. In Leg 41 sediments this species is restricted to the Pliocene-Pleistocene boundary of Site 366, occurring only in large specimens (Samples 366A-4-1 and 366A-3, CC).

The species has been described from the same age of Tasman Basin (Theyer, 1973), of the Gulf Coast (Lamb and Beard, 1972, given as "Globorotalia inflata [variant]"), and from the Caribbean DSDP Sites 23, 25, 29 of Pliocene to early Pleistocene age (Bolli, 1970 , p. 580 , pl. 4, fig. 17-20, given as Globorotalia crassaformis A).

\section{Globorotalia truncatulinoides (d'Orbigny)}

(Plate 7, Figures 1,2)

Globorotalia (G.) truncatulinoides truncatulinoides (d'Orbigny)-Blow, 1969, p. 403, pl. 5, fig. 10-12, pl. 49, fig. 6 (neotype).

Range according to Blow (1969, p. 370): from the base of Zone N. 22 to Zone N.23.

We have encountered thin-walled and thicker-walled specimens, but we have not differed between $G$. truncatulinoides pachytheca and G. truncatulinoides truncatulinoides. Coiling direction is generally to the right, but statistics are not significant due to small numbers counted.

Occurrence in Leg 41 sites: 366A: from 3, CC to 1-1 (PleistoceneHolocene), few to common, permanently common in the later part of the Globigerina calida calida Subzone; 367: from 1, CC to 1-1 (Pleistocene-Holocene); 368: from 3, CC to 1-1 (PleistoceneHolocene), missing in the later part of the Globorotalia crassaformis viola Subzone, common from 2, CC (Globorotalia calida calida Subzone); 369: within 1-1 (Pleistocene); 370: from 1, CC (mixed fauna, Pleistocene).

\section{Globorotalia tumida tumida (Brady)}

(Plate 5, Figures 8-10)

Globorotalia menardii (d'Orbigny) var. tumida (Brady)-Banner and Blow, 1960 , p. 26, fig. la-c (lectotype).

Range according to Blow (1969): From the base of Zone N.18 to Recent.

Remarks: Lamb and Beard (1972) differed between G. tumida s.l., starting with the base of the Pliocene together with Globorotalia margaritae, Pulleniatina primalis, Globorotalia multicamerata, and Candeina nitida in the Gulf of Mexico and the Caribbean region, and $G$. tumida s.str., which is restricted to the Holocene. In DSDP'Sites 148 and 154 (Caribbean) Bolli and Premoli Silva (1973) reported G. tumida since the $G$. tosaensis Zone. According to Kennett (1973) $G$. tumida appears within the early Pliocene G. margaritae-Zone in the southwest Pacific.

Globorotalia tumida is considered to be a tropical-subtropical species.
Occurrences in Leg 41 sites: 366A: from 9 (G. margaritae margaritae Zone) with questionable forms, more distinct since 6-1 (Globorotalia margaritat evoluta Zone), common from 1, CC (late Pleistocene) to 1-1;367: from 5, CC to $1-1$ (mixed faunas no older than Pliocene to Pleistocene); 368: from 6, CC to 1-1 (Globorotalia margaritae margaritae Zone to Recent); 369: from 4-4 (Globorotalia margaritae margaritae Zone) to 1-3 (Globorotalia margaritae evoluta Zone); 370: none.

\section{Globorotalia tumida flexuosa (Koch)}

(Plate 5, Figures 11,12)

Globorotalia tumida flexuosa (Koch)-Bolli, 1970, p. 583, pl. 6, fig. 10-12.

Range according to Blow (1969): from the base of Zone N.18 to Zone N.22. Lamb and Beard (1972) recorded this subspecies within the Pleistocene only (Gulf of Mexico), as well as Bolli and Premoli Silva (1973) in the Caribbean.

Remarks: This subspecies, different to Globorotalia menardii neoflexuosa (see Srinivasan et al., 1974), became extinct in the Atlantic near the end of the last interglacial of the Pleistocene. $G$. tumida flexuosa belongs to the tropical-subtropical assemblage.

Occurrence in Leg 41 sites: $366 \mathrm{~A}: 1-3$ to $1-1$ (Globigerina calida calida Subzone); 367: 2,CC, to 1,CC (Pleistocene, mixed faunas); 368: $1-4$ to 1-3 (Globigerina calida calida/Globorotalia hessi Subzones); 369: none; 370: none.

\section{Globorotalia ungulata Bermudez}

(Plate 5, Figures 5-7)

Globorotalia ungulata Bermudez, 1960, p. 1304, pl. 15, fig. 6.

Remarks: Specimens from Leg 41 are of the elongated outlines as given for Globorotalia ungulata by Lamb and Beard (1972, pl. 11, fig. 7-9). The difference against $G$. tumida plexus is given by the less robust test and keel, and the menardii-like outline of the spiral side. Against Globorotalia cultrata it differs by the more rapidly engrowing test diameter and by the tumida-like shape in peripheral view. Intergrades seem to exist to both, $G$. tumida and $G$. cultrata.

Occurrences in Leg 41 sites: scattered and rare in the uppermost core of Site 366, attributed to the Globigerina calida calida Subzone. Isolated occurrences in Samples 366-2-4 and 366-2, CC may be due to technical reworking.

\section{NOTES TO THE ULTRASTRUCTURES}

In the following we deal with observations on the ultrastructure of the outer wall surfaces of selected species, in most cases from the last chambers. On the plates we have grouped the species mainly according to similarities in those ultrastructures, given for better comparison in uniform magnifications. Though we have selected them from a lot of scanning electron micrographs, we know that we are far from a complete knowledge of the interpretation of the different peculiarities in the ultrastructures. More studies have to be done to clarify the influence of ecological and diagenetical factors on the microtopography of the tests. However, the ultrastructures, in combination with gross morphologic features, may permit systematic classification of the Globigerinacea.

\section{Spinose Ultrastructure}

The spinose ultrastructure with pores is given for the genera Globigerina, Globigerinella, and Globigerinoides. The first two have rounded pores in pore pits, separated by broad interpore regions. Spines are only occasionally visible in subsurface samples, but a spinosity can be deduced by the presence of perforations which have another character than the pores, mostly situated on pustule-like elevations. The spines are irregularly distributed in the interpore areas, mostly protruding from elevated spine bases. In Globigerina 
(Beella) digitata digitata the divides are elevated to sharpened ridges, forming an irregular meshwork.

In Globigerinoides the arrangement of the spines is more regular, the spine bases being distinctly elevated. The circular pores show steep flanges. The last chambers of Globigerinoides ruber, G. elongatus, $G$. tenellus, and $G$. trilobus sacculifer have no elevated divides, but on the earlier chambers there are additional calcite layers on the divides as in Globigerinoides trilobus trilobus (Plate 3, Figure 10b), forming a polygonal net. Here the divides are nearly straight, having steep flanges and sharpened summits. In Globigerinoides conglobatus the calcification follows another scheme, the junctions of the divides are thickened in a more radial way, partly closing the pores and forming pseudospines in the umbilical region and on the earlier chambers.

\section{Porous Nonspinose Ultrastructure}

The porous nonspinose ultrastructure is recorded in the genera Globorotalia and Globorotaloides.

Pores of various diameters penetrate an even surface. The secondary calcification starts with single pustules mainly in the umbilical region, overgrowing the pores of the earlier chambers. In some cases (for instance, Globorotalia bermudezi, Plate 4, Figure 14) the pustules are pointed, forming pseudospines in the umbilical region. The keel in the $G$. cultrata-tumida group is another region for progressive calcification, sometimes reaching the stadium of euhedral crystallization.

Globorotalia triangula and Globorotalia inflata are separated from the other Globorotalias by their smoothened surfaces. The calcification takes place in more uniform layers, closing the pores in $G$. triangula nearly totally on all chambers. Some very fine slits may be interpreted as remnants of the pores. Heavy pustules are restricted to the apertural region. In Globorotalia inflata they are spread nearly over the total umbilical side, which has a very low porosity, while the spiral side is highly porous. The secondary calcite crust closing the pores is visible mainly on the earlier chambers of the spiral side.

Globorotaloides hexagonus (Plate 4, Figure 9b) has an ultrastructure, which is quite similar to that of Globigerinoides, but spineholes could not be detected. The mostly hexagonal dividers are straight, pores being rounded, in the center of the pore pits, which show slightly inclined flanges. The junctions of the divides are slightly elevated to pseudospines, especially in the vicinity of the aperture.

Turborotalita and the Neogloboquadrina plexus (including "Globorotalia" pseudopima and "Globigerina" pachyderma/incompta) belongs to the porousnonspinose group, too. But the calcification is different to the above-mentioned Globorotalias. The rounded pores primarily are of more equal size. Pustules are missing. The secondary calcification is managed by a thickening of the divides, which close the pores partially on the earlier chambers. Pseudospines are formed in the umbilical region below the aperture by pronounced elevated junctions of the divides. Heavy calcification may reach the stadium of euhedral crystallinity.

\section{Perforated, Pustulose Ultrastructure}

This kind of ultrastructure is recorded in Globigerinita and Candeina. Globigerinita glutinata (Plate 2, Figure 2b) shows an even, microcrystalline surface, penetrated by numerous, somewhat irregularly arranged perforations of about $0.5 \mu \mathrm{m}$ in diameter. The surface is overgrown by a great many, subconical pustules, which are separated on the youngest chambers, but united on the earlier ones, forming a coarse crystalline layer. Real pores may be observed in some earlier chambers on the spiral side, as well as singular in Candeina nitida (Plate 2, Figure 3a). The fine holes in the surface of Globigerinita uvula are intermittent between perforations and pores, if we use the definitions of Collen and Vella (1973).

\section{REFERENCES}

Bạndy, O.L., Casey, R.E., and Wright, R.C., 1971. Late Neogene planktonic zonation, magnetic reversals, and radiometric dates, Antarctic to tropics: Am. Geophys. Union Antarctic Res. Ser., v. 15 (Antarctic Oceanology, v. 1), p. 1 .

Bandy, O.L., Frerichs, W.E., and Vincent, E., 1969. Origin, development, and geologic significance of Neogloboquadrina Bandy, Frerichs, and Vincent, gen. nov.: Cushm. Found. Foram. Res. Contrib., v. 18, p. 152.

Banner, F.T. and Blow, W.H., 1960. Some primary types of species belonging to the superfamily Globigerinaceae. Cushm. Found. Foram. Res. Contrib., v. 11, p. 1.

Bé, A.W.H., 1960. Ecology of Recent planktonic foraminifera: Part 2-Bathymetric and seasonal distributions in the Sargasso Sea off Bermuda: Micropaleontology, v. 6, p. 373 .

1967. Foraminifera. Families: Globigerinidae and Globorotaliidae. Fiches d'ident. Zooplancton, Charlottenlund Slot, Danemark, Sheet 108.

Bermudez, P.J., 1960. Contribucion al estudio de las Globigerinidea de la region Caribe-Antillana (PaleocenoReciente): Mem. Third Congr. Geol. Venez. Bol. Geol., Caracas, p. 1119.

Blow, W.H., 1969. Late middle Eocene to Recent Planktonic foraminiferal biostratigraphy: First Int. Conf. Plankt. Microfoss. Proc., Geneva 1967, p. 199.

Bolli, H.M., 1957. Planktonic Foraminifera from the Oligocene-Miocene Cipero and Lengua Formations of Trinidad, B.W.I.: U.S. Nat. Mus. Bull. 215, p. 97. , 1970. The foraminifera of Sites 23-31, Leg 4. In Bader, R.G., Gerard, R.D., et al., Initial Reports of the Deep Sea Drilling Project, Volume 4: Washington (U.S. Government Printing Office), p. 577.

Bolli, H.M., Loeblich, A.R., Jr., and Tappan, H., 1957. Planktonic foraminiferal families Hantkeninidae, Orbulinidae, Globorotaliidae and Globotruncanidae: U.S. Nat. Mus. Bull. 215 , p. 3.

Bolli, H.M. and Premoli Silva, I, 1973. Oligocene to Recent planktonic foraminifera and stratigraphy of the Leg 15 sites in the Caribbean Sea. In Edgar, T.N., Saunders, J.B., et al., Initial Reports of the Deep Sea Drilling Project, Volume 15: Washington (U.S. Government Printing Office), p. 475.

Brady, H.B., 1884. Report on the foraminifera dredged by H.M.S. Challenger, during the years 1873-1876: Rept. Voy. Challenger, Zool., v. 9.

Cifelli, R., 1961. Globigerina incompta, a new species of pelagic foraminifera from the North Atlantic: Cushm. Found. Foram. Res. Contrib., v. 12, p. 83. 
Collen, J.D. and Vella, P., 1973. Pliocene planktonic foraminifera, southern North Island, New Zealand: Jr. Foram. Res., v. 3, p. 13.

d'Orbigny, A., 1826. Tableau Méthodique de la classe des Céphalopodes: Arn. Sci. Nat., Paris, ser. 1, v. 7. p. 96. 1839. Foraminiferes: In R. de la Sagra, Histoire physique, politique et naturelle de l'île de Cuba: Paris (Bertrand), p. 1-224.

Egger, J.G., 1893. Foraminiferen aus Meeresgrundproben, gelothet von 1874 bis 1876 von S.M.Sch. Gazelle: Abh. K. Bayr. Akad. Wiss., v. 18, p. 195.

Ehrenberg, C.G., 1861. Elemente des tiefen Meeresgrundes im Mexikanischen Golfstrom bei Florida, über die Tiefgrund-Verhältnisse des Oceans am Eingange der Davisstrasse und bei Island: K. Preuss. Akad. Wiss., Berlin, Monatsber., p. 222.

Galloway, J.J. and Wissler, S.G., 1927. Pleistocene foraminifera from the Lomita Quarry, Palos Verdes Hills, California: J. Paleont., v. 1, p. 35.

Hays, J.D., Saito, T., Opdyke, N.D., and Burckle, L.H., 1969. Pliocene-Pleistocene sediments of the equatorial Pacific: Their paleomagnetic, biostratigraphic, and climatic record: Geol. Soc. Am. Bull., v. 80, p. 1481.

Hofker, J., 1956. Foraminifera Dentata. Foraminifera of Santa Cruz and Thatch-Island, Virginia Archipelago, West Indies: Copenhagen Univ. Zool. Mus. Spolia, v. 15, p. 9.

Kennett, J.P., 1973. Middle and late Cenozoic planktonic foraminiferal biostratigraphy of the southwest PacificDSDP, Leg 21. In Burns, R.E., Andrews, J.E., et al., Initial Reports of the Deep Sea Drilling Project, Volume 21: Washington (U.S. Government Printing Office), p. 575 .

Lamb, J.L. and Beard, J.H., 1972. Late Neogene planktonic foraminifers in the Caribbean, Gulf of Mexico, and Italian stratotypes: Kansas, Univ. Paleontol. Contrib., No. 57 (Protozoa, art. 8).

Natland, M.L., 1938. New species of Foraminifera from off the west coast of North America and from the later Tertiary of the Los Angeles basin: Scripps Inst. Oceanogr. Univ. Calif. Tech. Ser. Bull. 4, p. 137.

Parker, F.L., 1958. Eastern Mediterranean foraminifera: Swedish Deep-Sea Exped. Rept., v. 8, p. 219.
1962. Planktonic foraminiferal species in Pacific sediments: Micropaleontology, v. 8, p. 219.

Poore, R.Z. and Berggren, A.W., 1975. The morphology and classification of Neogloboquadrina atlantica (Berggren): J. Foram. Res., v. 5, p. 76.

Reuss, A.E., 1850. Neue Foraminiferen aus den Schichten des oesterreichischen Tertiärbeckens. K. Akad. Wiss. Wien, Math.-Naturwiss. Cl., Denkschr., v. 1, p. 365.

Rögl, F., 1974. The evolution of the Globorotalia truncatulinoides and Globorotalia crassaformis group in the Pliocene and Pleistocene of the Timor trough, DSDP Leg 27, Site 262. In Veevers, J.J., Heirtzler, J.R., et al., Initial Reports of the Deep Sea Drilling Project, Volume 27: Washington (U.S. Government Printing Office), p. 743.

Rögl, F. and Bolli, H.M., 1973. Holocene to Pleistocene Planktonic foraminifera of Leg 15, Site 147 (Cariaco Basin [Trench], Caribbean Sea) and their climatic interpretation. In Edgar, N.T., Saunders, J.B., et al., Initial Reports of the Deep Sea Drilling Project, Volume 15: Washington (U.S. Government Printing Office), p. 553.

Saito, T., Thompson, P.R., and Breger, D., 1976. Skeletal ultramicrostructure of some elongate-chambered planktonic foraminifera and related species. In "Progress in micropaleontology," Spec. publ: New York (Micropaleontology Press, Am. Mus. Nat. History), p. 278.

Srinivasan, M.S. and Kennett, J.P., 1976. Evolution and phenotypic variation in the Late Cenozoic Neogloboquadrina dutertrei plexus. In Progress in micropaleontology, Spec. Publ.: New York (Micropaleontology Press, Am. Mus. Nat. History), p. 329.

Srinivasan, M.S., Kennett, J.P., and Be, A.W.H., 1974. Globorotalia menardii neoflexuosa new subspecies from the northern Indian Ocean: Deep-Sea Res., v. 21, p. 321.

Stainforth, R.M., Lamb, J.L., Luterbacher, H.P., Beard, J.H., and Jeffords, R.M., 1975. Cenozoic planktonic foraminiferal zonation and characteristics of index forms: Univ. Kansas Paleontol. Contrib. Art. 62, p. 1.

Theyer, F., 1973. Globorotalia inflata triangula, a new planktonic foraminiferal subspecies: J. Foram. Res., v. 3, p. 199.

Zobel, B., 1968. Phänotypische Varianten von Globigerina dutertrei d'Orbigny (Foram.); ihre Bedeutung für die Stratigraphie in quartären Tiefsee-Sedimenten: Geol. Jb., v. 85, p. 97. 


\section{PLATE 1}

Figures 1-4 Globigerinella siphonifera (d'Orbigny).

Sample 366A-1, CC.

1a. Lateral view, $\times 75$.

lb. Ultrastructure of the lateral part of the last chamber, $\times 1000$.

2. Peripheral view, $\times 75$.

3. Lateral view (initial volutions display trochospiral coiling), $\times 75$.

4. Lateral view of an irregularly coiled specimen, $\times 75$.

Figures 5-7 Globigerina calida Parker.

Sample 366A-1, CC.

5a. Spiral view, $\times 75$.

5 b. Ultrastructure of the spiral side of the last chamber, $\times 1000$.

6. Peripheral view, $\times 75$.

7. Umbilical view, $\times 75$.

Figures 8-10 Globigerina bulloides d'Orbigny.

Sample 366A-1, CC.

8. Umbilical view, $\times 75$.

9. Peripheral view, $\times 75$.

10a. Spiral view, $\times 75$.

10b. Ultrastructure of the spiral side of the last chamber, $\times 1000$.

Figures 11-13 Globigerina rubescens Hofker.

Sample 366A-1, CC.

11. Umbilical view, $\times 150$.

12. Peripheral view, $\times 150$.

13a. Spiral view, $\times 150$.

13b. Ultrastructure of the spiral side of the last chamber, $\times 1000$.

Figure 14 Globigerina (Beella) digitata digitata Brady.

Sample 366A-2,CC.

14a. Spiral view, $\times 75$.

14b. Ultrastructure of the spiral side of the last chamber, $\times 1000$.

Figures 15,16 Globigerina (Beella) digitata aff. praedigitata Parker.

Sample 366A-2, CC.

15. Umbilical view, $\times 75$.

16a. Umbilical view, $\times 75$.

16b. Ultrastructure of the umbilical side of the last chamber, $\times 1000$. 

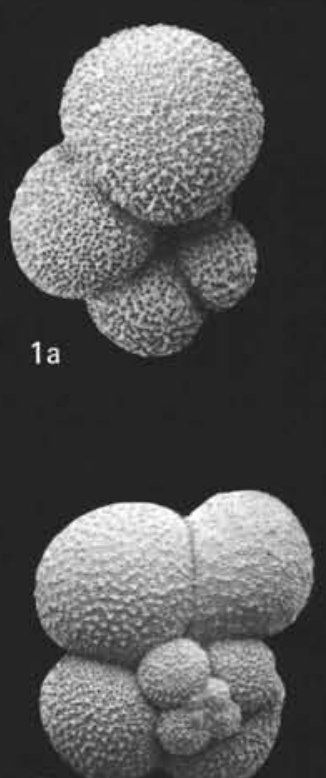

$5 a$
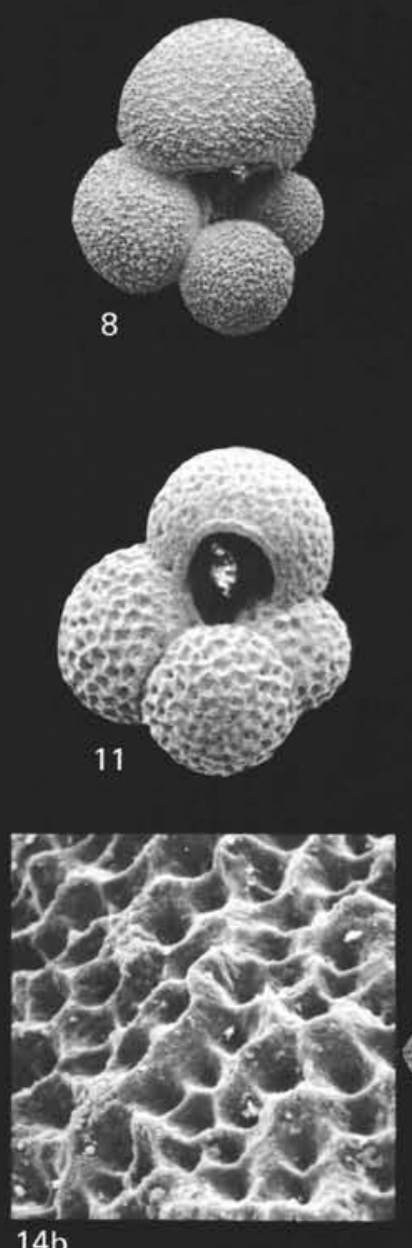
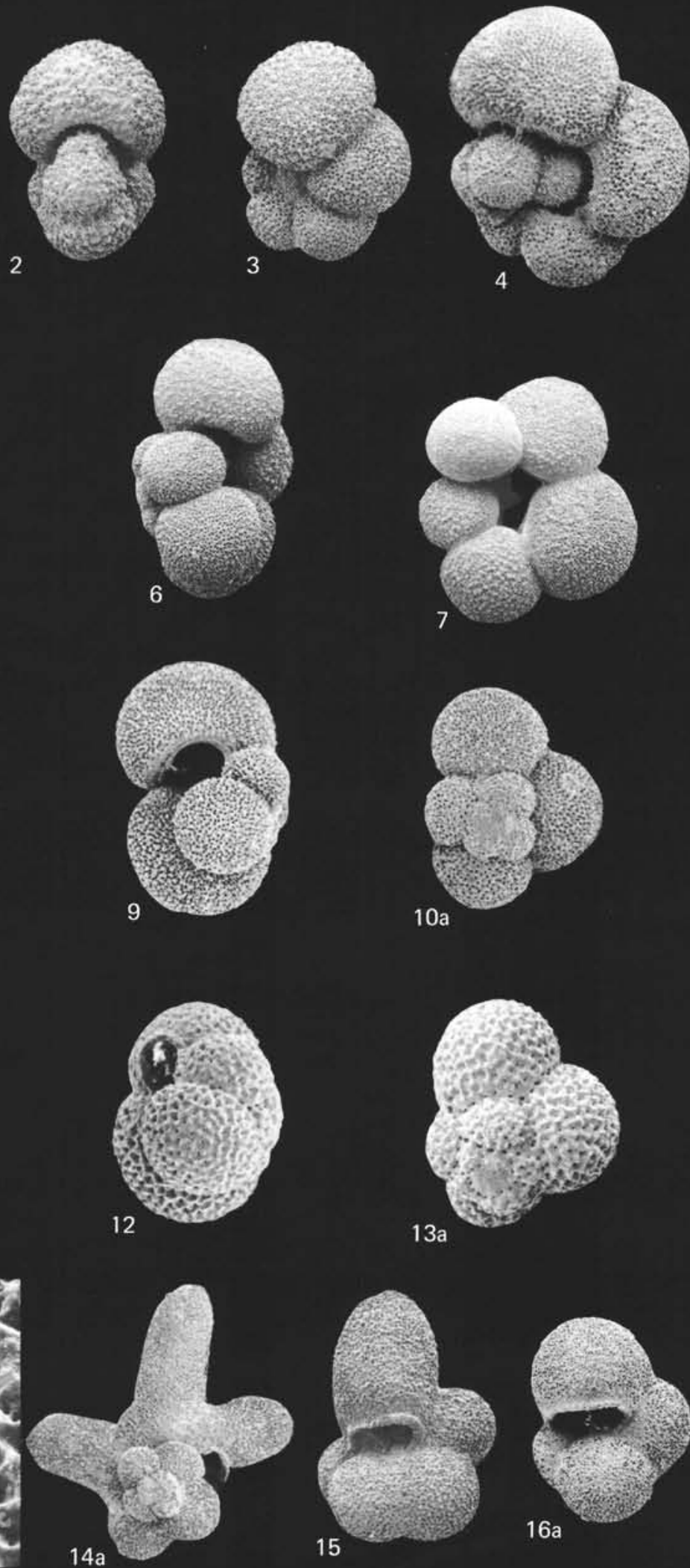

$10 \mathrm{a}$

$13 a$

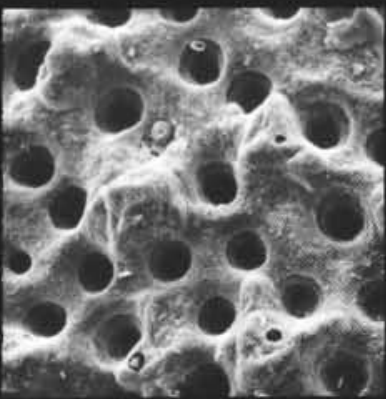

$1 b$

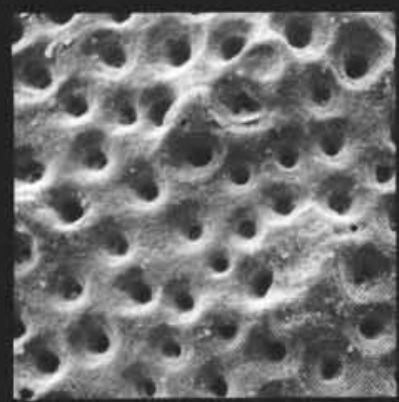
$5 b$

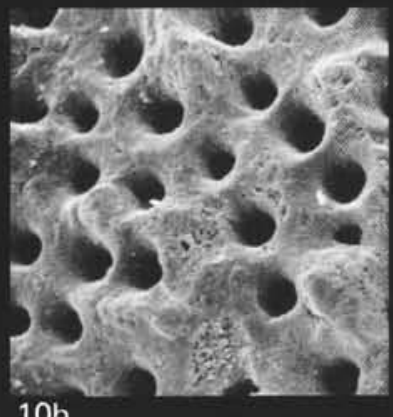

$10 \mathrm{~b}$

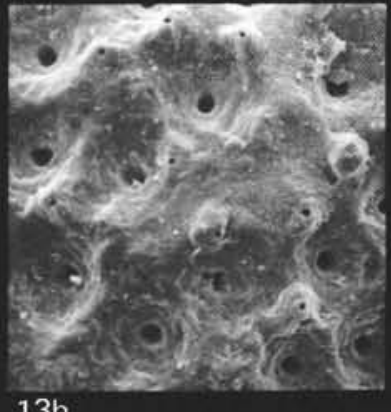

\section{$13 b$}

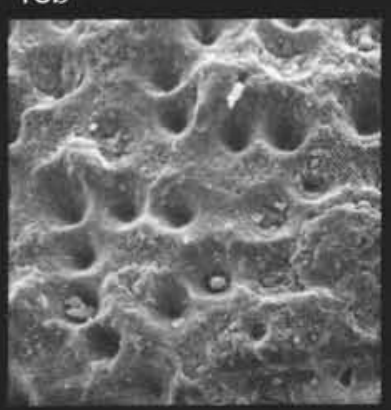

$16 b$ 


\section{PLATE 2}

Samples indicated as "(top)" were collected from the soupy top of the core. This unconventional indication is necessary to distinguish from other standard samples.

Figures 1-3 Candeina nitida d'Orbigny.

Sample 366A-1, CC.

1. Umbilical view, $\times 75$.

2. Peripheral view, $\times 75$.

3a. Spiral view, $\times 75$.

3b. Ultrastructure of the spiral side of the last chamber, $\times 1000$.

Figures 4-6 Globigerinita glutinata (Egger).

Sample 366-1-1 (top).

4a. Spiral view, $\times 75$.

4b. Ultrastructure of the spiral side of the last chamber, $\times 1000$.

5. Peripheral view, $\times 75$.

6. Umbilical view, $\times 75$.

Figures 7-9 Globigerinita uvula (Ehrenberg).

Sample 369-1,CC.

7a. Umbilical view, $\times 300$.

7b. Ultrastructure of the umbilical side of the last chamber, $\times 1000$.

8. Peripheral view, $\times 300$.

9. Spiral view, $\times 300$.

Figures 10-12 Globigerina quinqueloba Natland.

Sample 366-1-1 (top).

$10 \mathrm{a}$. Spiral side, $\times 300$.

10b. Ultrastructure of the spiral side of the last chamber, $\times 1000$.

11. Peripheral view, $\times 300$.

12. Umbilical view, $\times 300$.

Figures 13-15 Turborotalita humilis (Brady).

Sample 366-1-1 (top).

13a. Umbilical view, $\times 300$.

13b. Ultrastructure of the peripheral part of the last chamber, $\times 1000$.

14. Peripheral view, $\times 300$.

15. Spiral view, $\times 300$. 

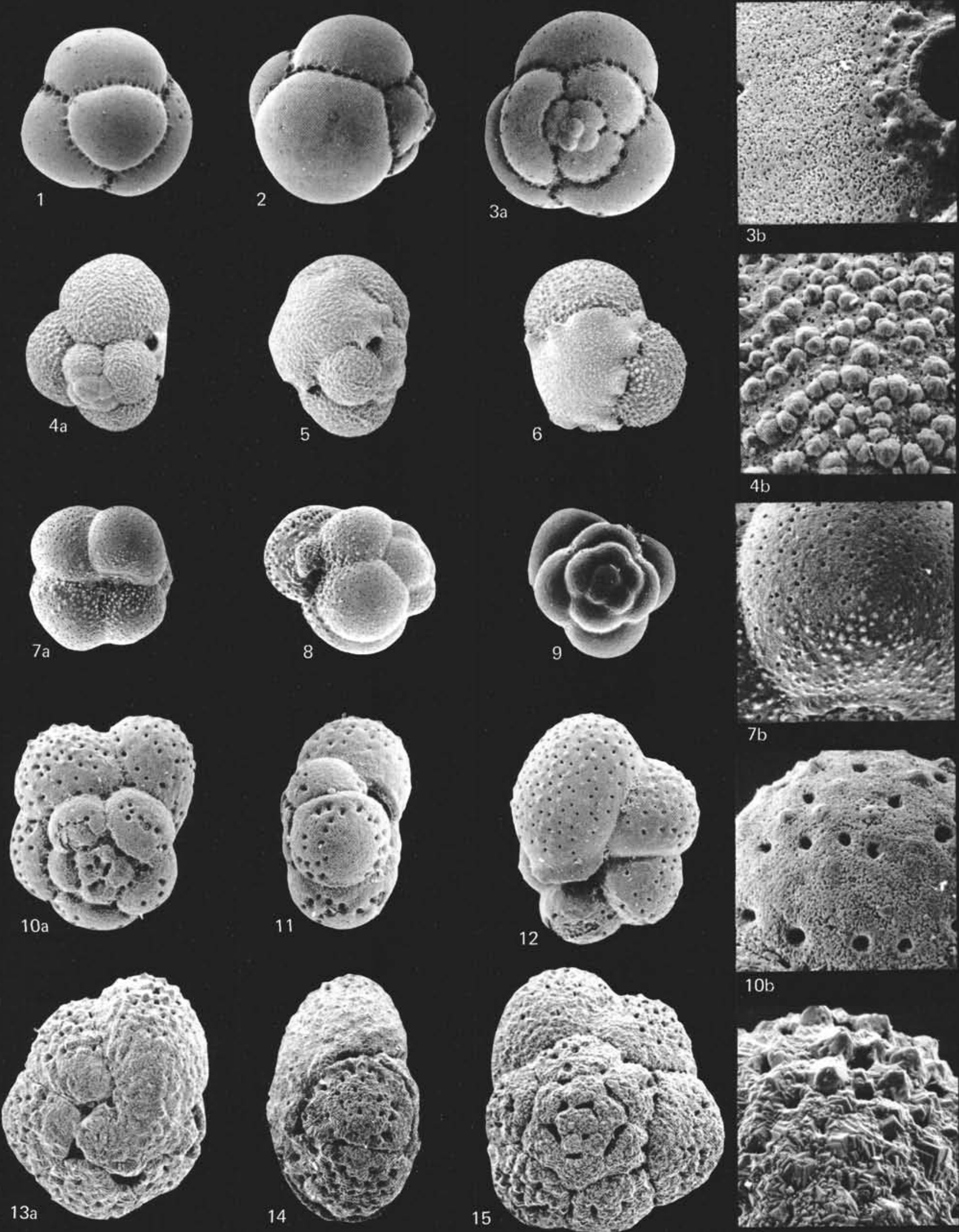

$7 b$

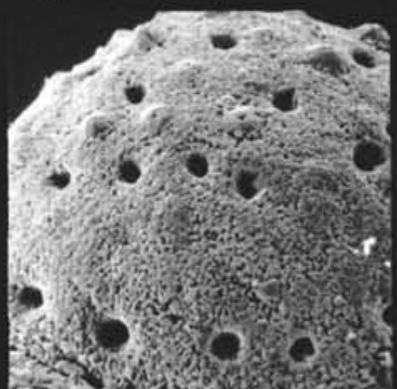

$10 \mathrm{~b}$

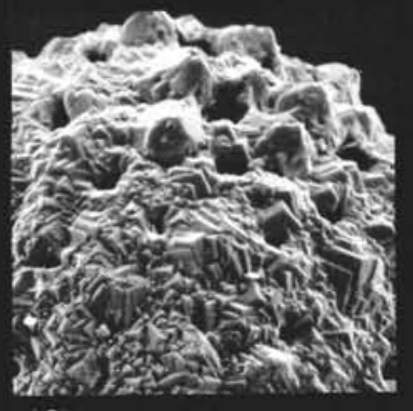




\section{PLATE 3}

Figures 1-3 Globigerinoides ruber (d'Orbigny), pink variety. Sample 366-1-1 (top).

1. Spiral view, $\times 75$.

2a. Peripheral view, $\times 75$.

$2 \mathrm{~b}$. Ultrastructure of the peripheral part of the antepenultimate chamber, $\times 1000$.

3. Umbilical view, $\times 75$.

Figures 4-6 Globigerinoides ruber (d'Orbigny), high-spired variety.

Sample 366-1-1 (top).

4a. Umbilical view, $\times 75$.

4b. Ultrastructure of the peripheral part of the last chamber, $\times 1000$.

5. Peripheral view, $\times 75$.

6. Spiral view, $\times 75$.

Figures 7-9 Globigerinoides elongatus (d'Orbigny).

Sample 366A-1, CC.

7a. Umbilical view, $\times 75$.

7b. Ultrastructure of the peripheral part of the last chamber, $\times 1000$.

8. Peripheral view, $\times 75$.

9. Spiral view, $\times 75$.

Figures 10-12 Globigerinoides trilobus trilobus (Reuss).

Sample 366-1-1.

10a. Umbilical view, $\times 75$.

10b. Ultrastructure of the umbilical side of the last chamber, $\times 1000$.

11. Peripheral view, $\times 75$.

12. Spiral view, $\times 75$.

Figures 13-15 Globigerinoides trilobus sacculifer (Brady). Sample 366-1-1 (top).

13. Umbilical view, $\times 75$.

14. Peripheral view, $\times 75$.

15a. Spiral view, $\times 75$.

15b. Ultrastructure of the spiral side of the last chamber, $\times 1000$. 

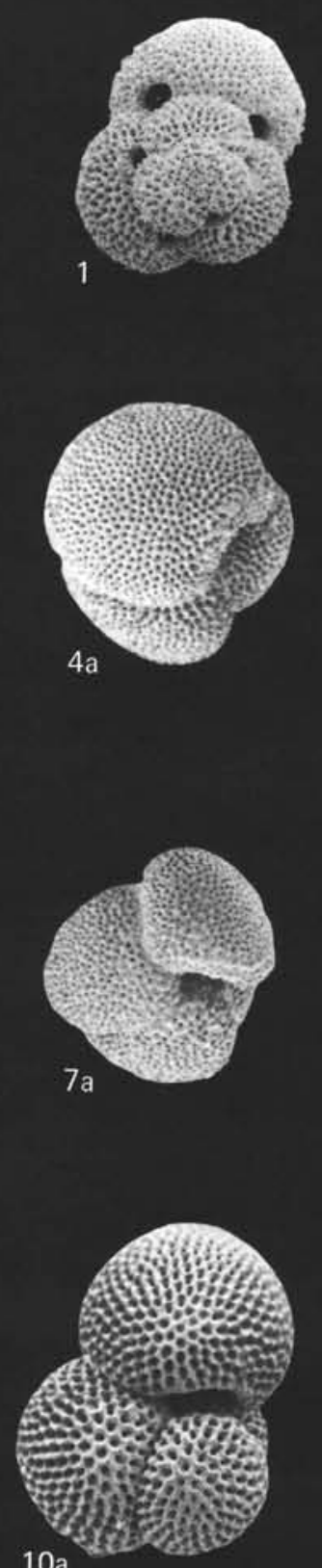

$10 \mathrm{a}$

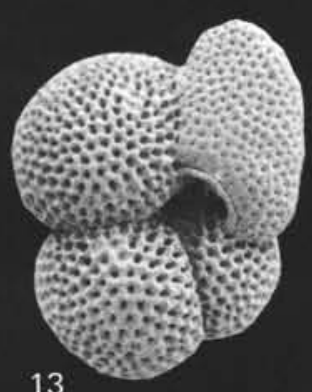

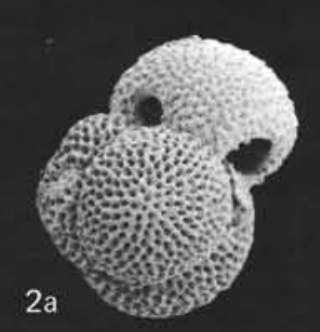
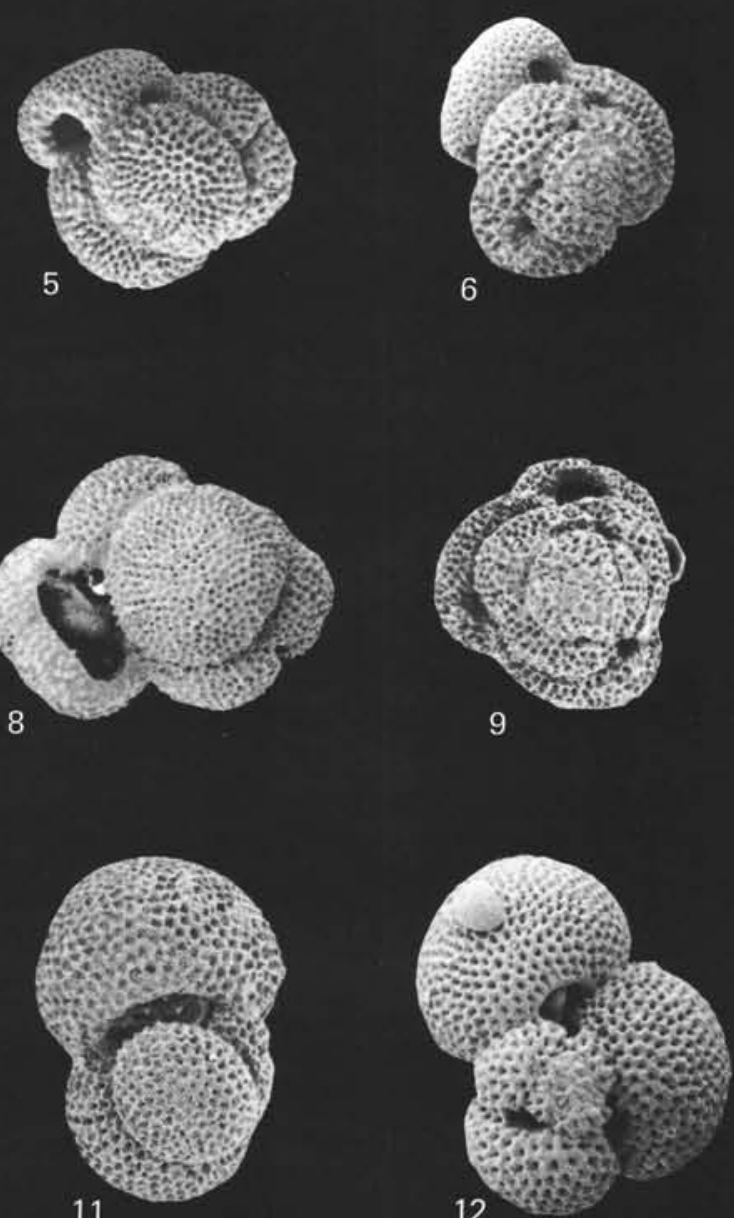

11
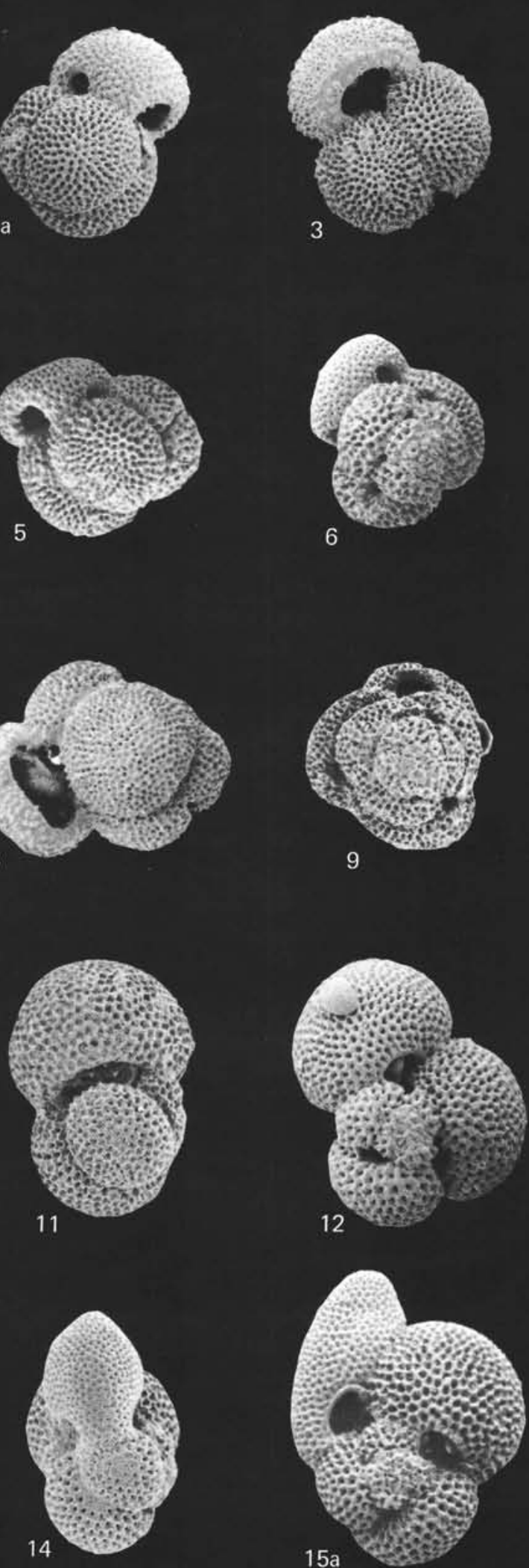
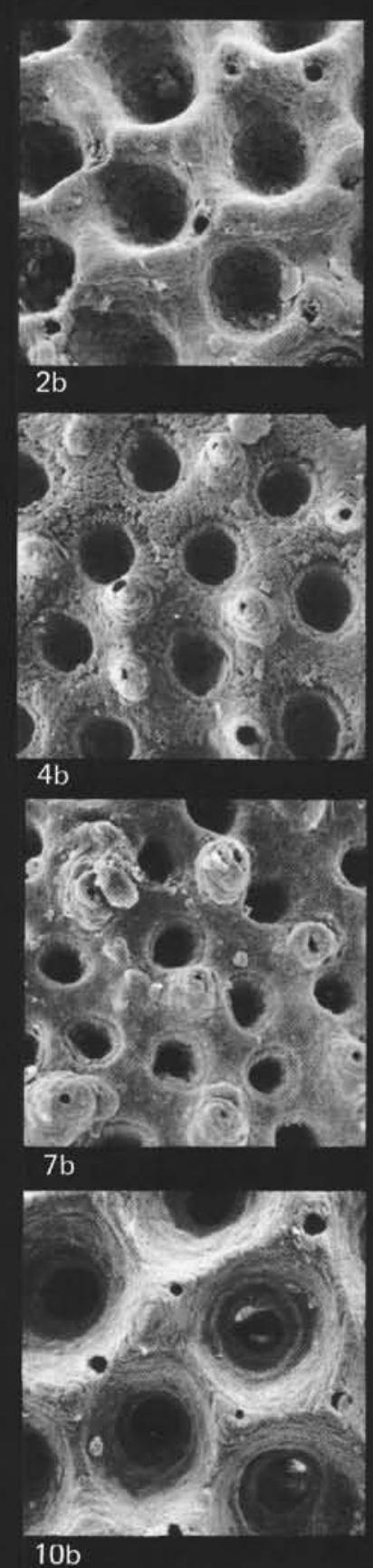


\section{PLATE 4}

Figures 1-3 Globigerinoides tenellus Parker.

Sample 366A-1, CC.

1a. Spiral view, $\times 150$.

1b. Ultrastructure of the spiral side of the last chamber, $\times 1000$.

2. Peripheral view, $\times 150$.

3. Umbilical view, $\times 150$.

Figures 4-6 Globigerinoides conglobatus (Brady).

Sample 366A-1-3, 71-73 cm.

4. Spiral view, $\times 75$.

5. Peripheral oblique view, $\times 75$.

6a. Umbilical view, $\times 75$.

6b. Ultrastructure of the umbilical side of the last chamber, $\times 1000$.

Figures 7-9 Globorotaloides hexagonus (Natland).

Sample 366A-2, CC.

7. Spiral view, $\times 75$.

8. Peripheral view, $\times 75$.

9a. Umbilical view, $\times 75$.

9b. Ultrastructure of the umbilical side of the last chamber, $\times 1000$.

Figures 10-12 Globorotalia scitula (Brady).

Sample 366A-3,CC.

10a. Spiral view, $\times 75$.

10b. Ultrastructure of the spiral side of the last chamber, $\times 1000$.

11. Peripheral view, $\times 75$.

12. Umbilical view, $\times 75$.

Figures 13-15 Globorotalia bermudezi Rögl and Bolli.

Sample 368-1, CC.

13a. Spiral view, $\times 200$.

13b. Ultrastructure of the spiral side of the last chamber, $\times 1000$.

14. Peripheral view, $\times 200$.

15. Umbilical view, $\times 200$. 
PLATE 4
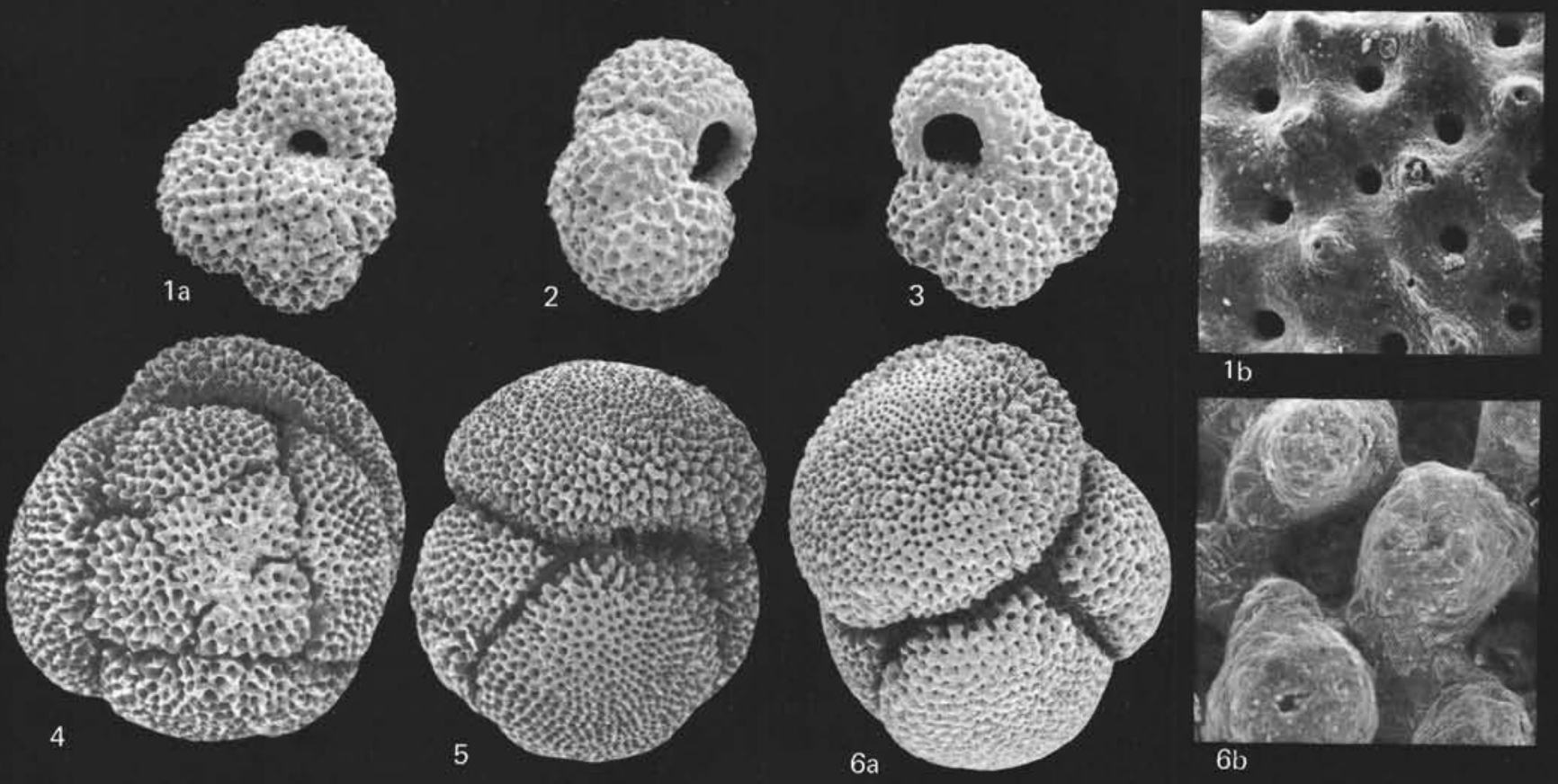

$1 b$
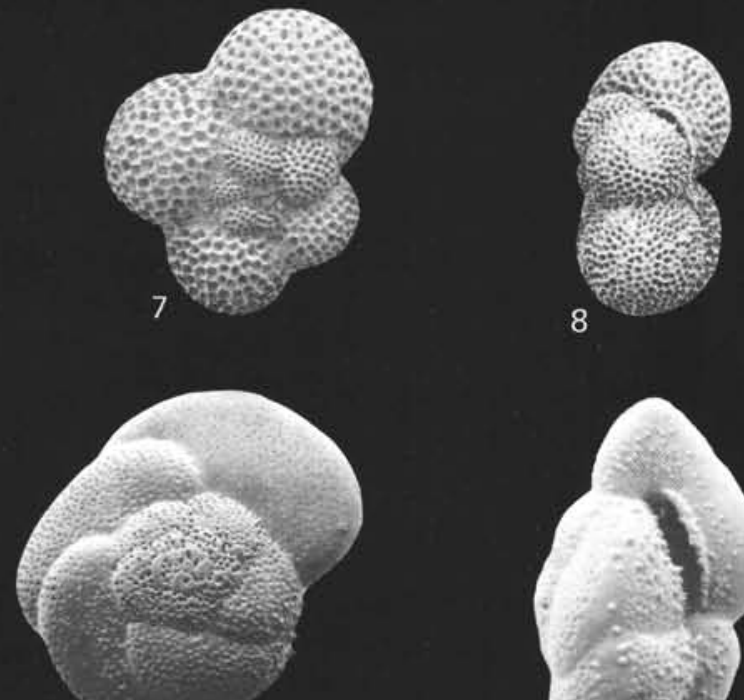

$10 \mathrm{a}$
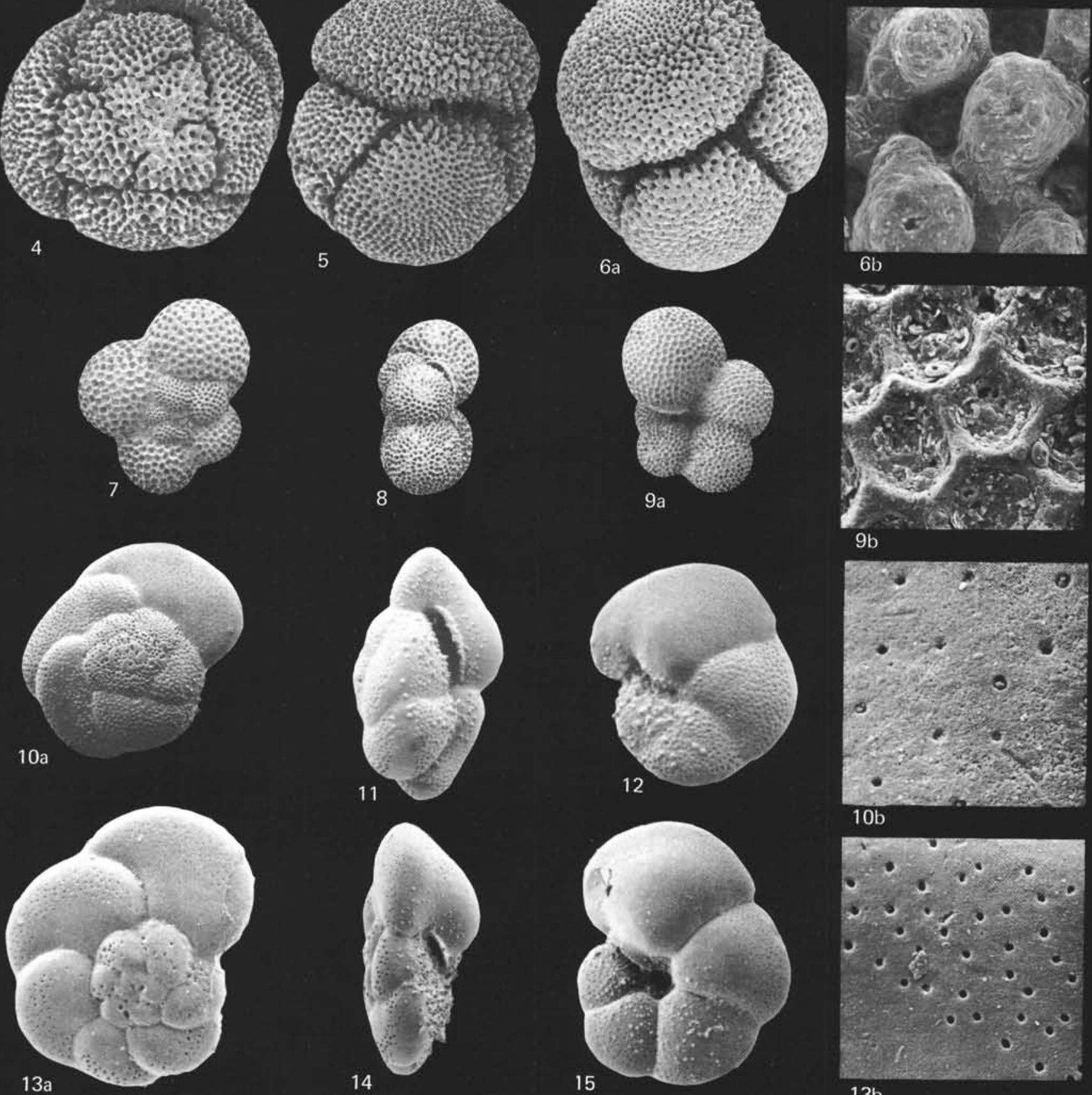
$6 b$
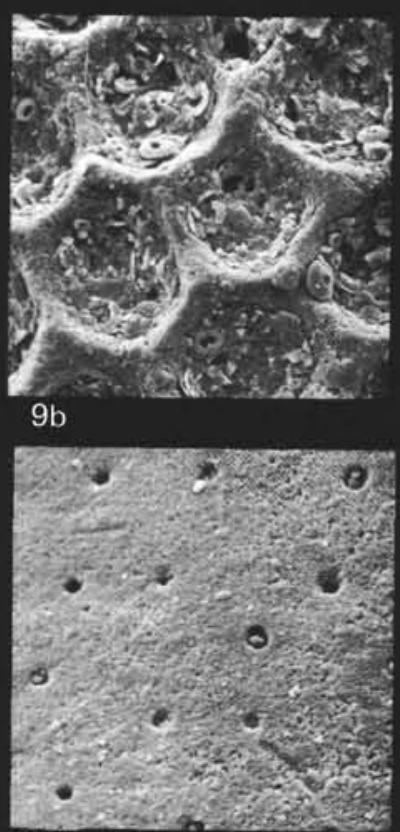

$10 \mathrm{~b}$
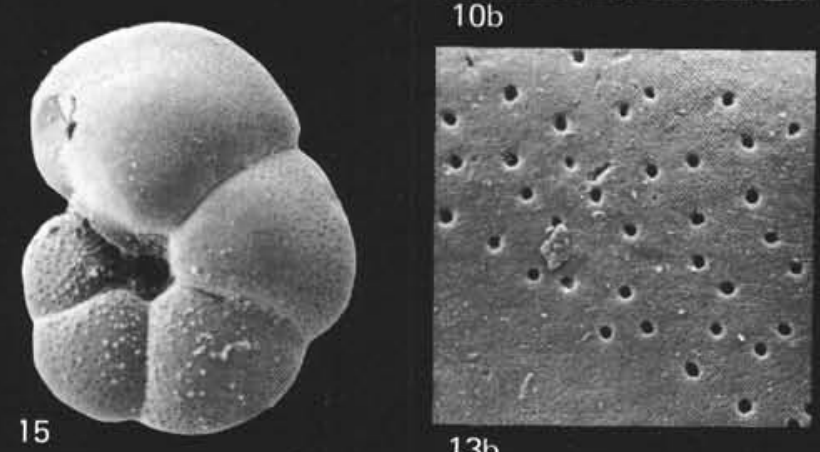


\section{PLATE 5}

Figure $1 \quad$ Globorotalia aff. fimbriata (Brady).

Sample 366A-1-4, 63-65 cm.

Umbilical view, $\times 50$.

Figures 2-4 Globorotalia cultrata (d'Orbigny).

Sample 366A-2, CC.

2. Umbilical view, $\times 50$.

3. Peripheral view, $\times 50$.

4a. Spiral view, $\times 50$.

4b. Ultrastructure of the spiral side of the last chamber, $\times 1000$.

Figures 5-7 Globorotalia ungulata Bermudez.

Sample 366A-1-2, 71-73 cm.

5 a. Umbilical view, $\times 50$.

5 b. Ultrastructure of the umbilical side of the last chamber, $\times 1000$.

6. Peripheral view, $\times 50$.

7. Spiral view, $\times 50$.

Figures 8-10 Globorotalia tumida tumida (Brady).

Sample 366A-1, CC.

8a. Umbilical view, $\times 50$.

$8 \mathrm{~b}$. Ultrastructure of the umbilical side of the last chamber, $\times 1000$.

9. Peripheral view, $\times 50$.

10. Spiral view, $\times 50$.

Figures 11, 12 Globorotalia tumida flexuosa Koch.

Sample 366A-1-3, 71-73 cm.

11. Umbilical view, $\times 50$.

12a. Peripheral view, $\times 50$.

12b. Spiral view, $\times 50$.

12c. Ultrastructure of the spiral side of the penultimate chamber, $\times 1000$. 


\section{PLATE 5}
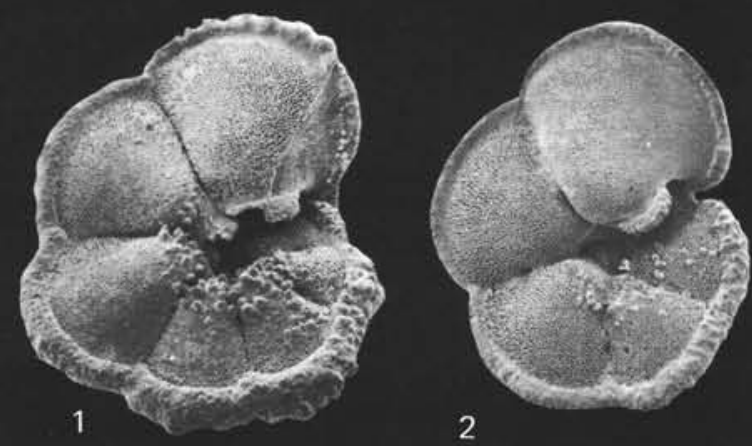

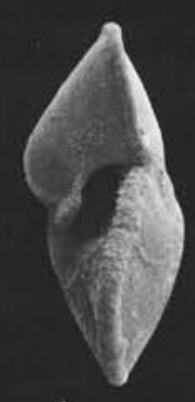

3

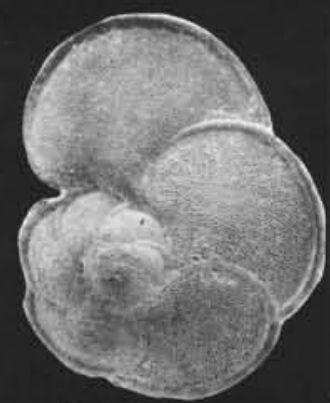

$4 \mathrm{a}$
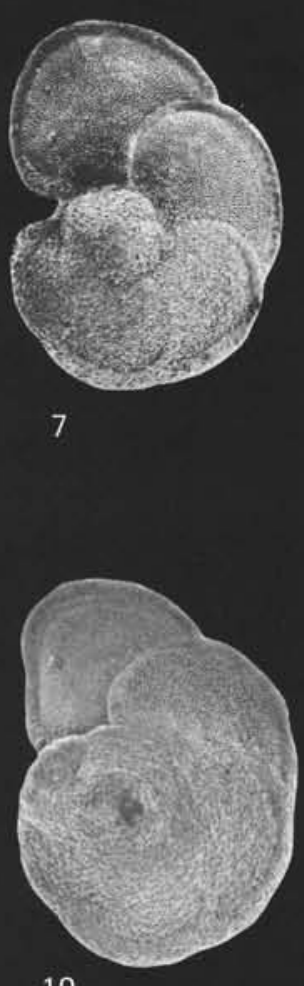

10

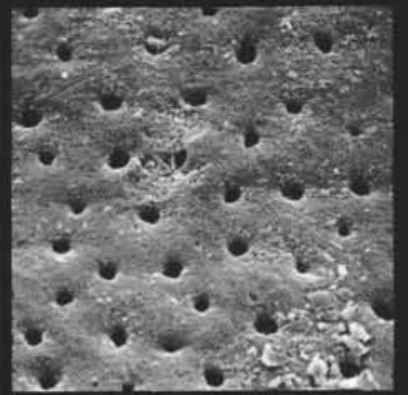

$8 b$
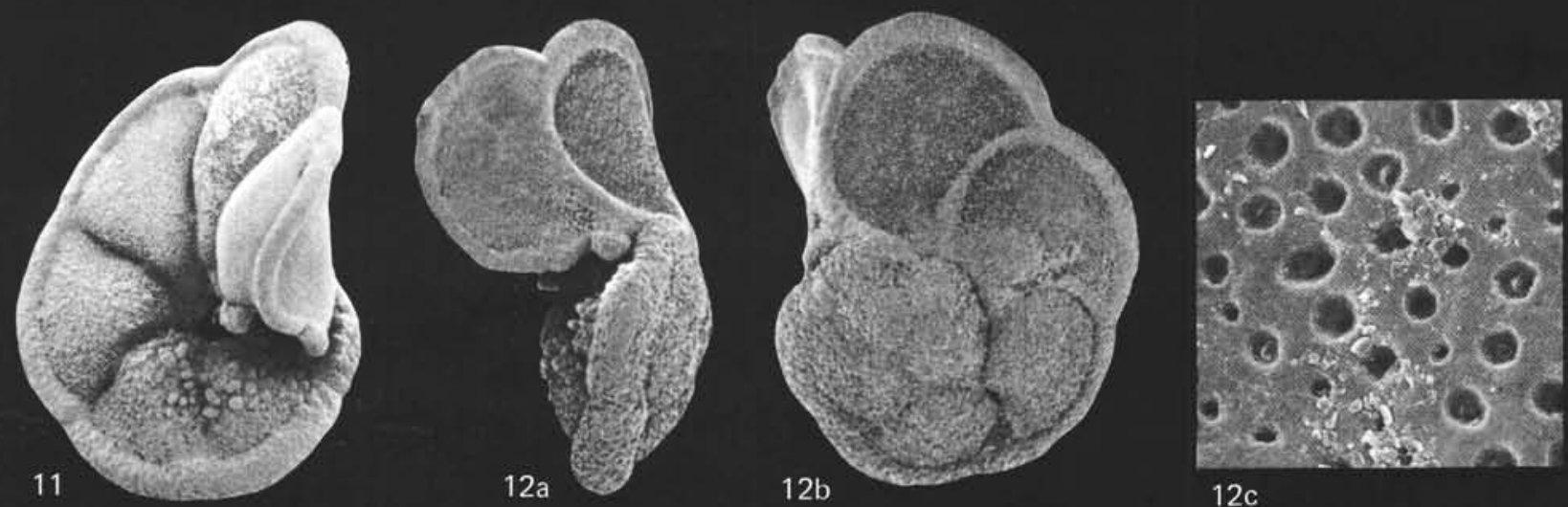


\section{PLATE 6}

Figures 1-3 Globorotalia crassaformis crassaformis (Galloway and Wissler).

Sample 366A-1, CC.

1. Umbilical view, $\times 75$.

2. Peripheral view, $\times 75$.

3a. Spiral view, $\times 75$.

3b. Ultrastructure of the spiral side of the penultimate chamber, $\times 1000$.

Figures 4-6 Globorotalia crassaformis hessi Bolli and Premoli Silva.

Sample 366A-1, CC.

4a. Umbilical view, $\times 75$.

4b. Ultrastructure of the umbilical side of the last chamber, $\times 1000$.

5. Peripheral view, $\times 75$.

6. Spiral view, $\times 75$.

Figures 7-9 Globorotalia crassaformis ronda Blow.

Sample 366A-1, CC.

7. Umbilical view, $\times 75$.

8. Peripheral view, $\times 75$.

9a. Spiral view, $\times 75$.

9b. Ultrastructure of the spiral side of the last chamber, $\times 1000$.

Figures 10-12 Globorotalia crassaformis viola Blow.

Sample 366A-3,CC.

10. Umbilical view, $\times 75$.

11. Peripheral view, $\times 75$.

12a. Spiral view, $\times 75$.

$12 \mathrm{~b}$. Ultrastructure of the spiral side of the last chamber, $\times 1000$. 
PLATE 6
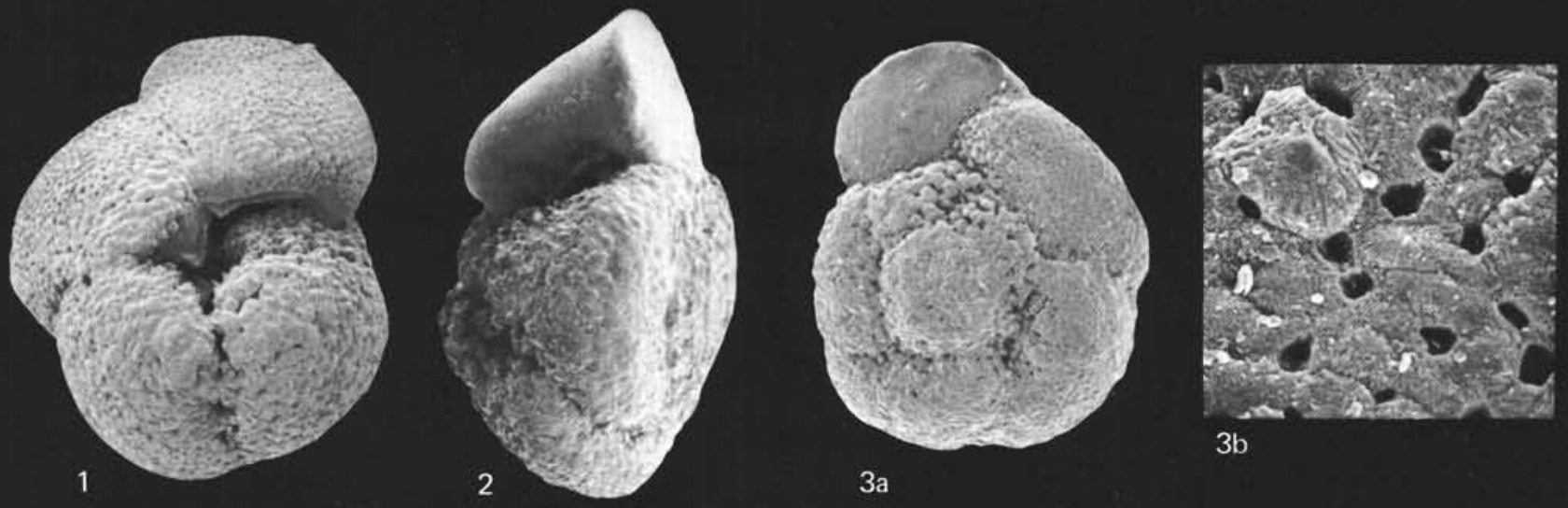

$3 b$
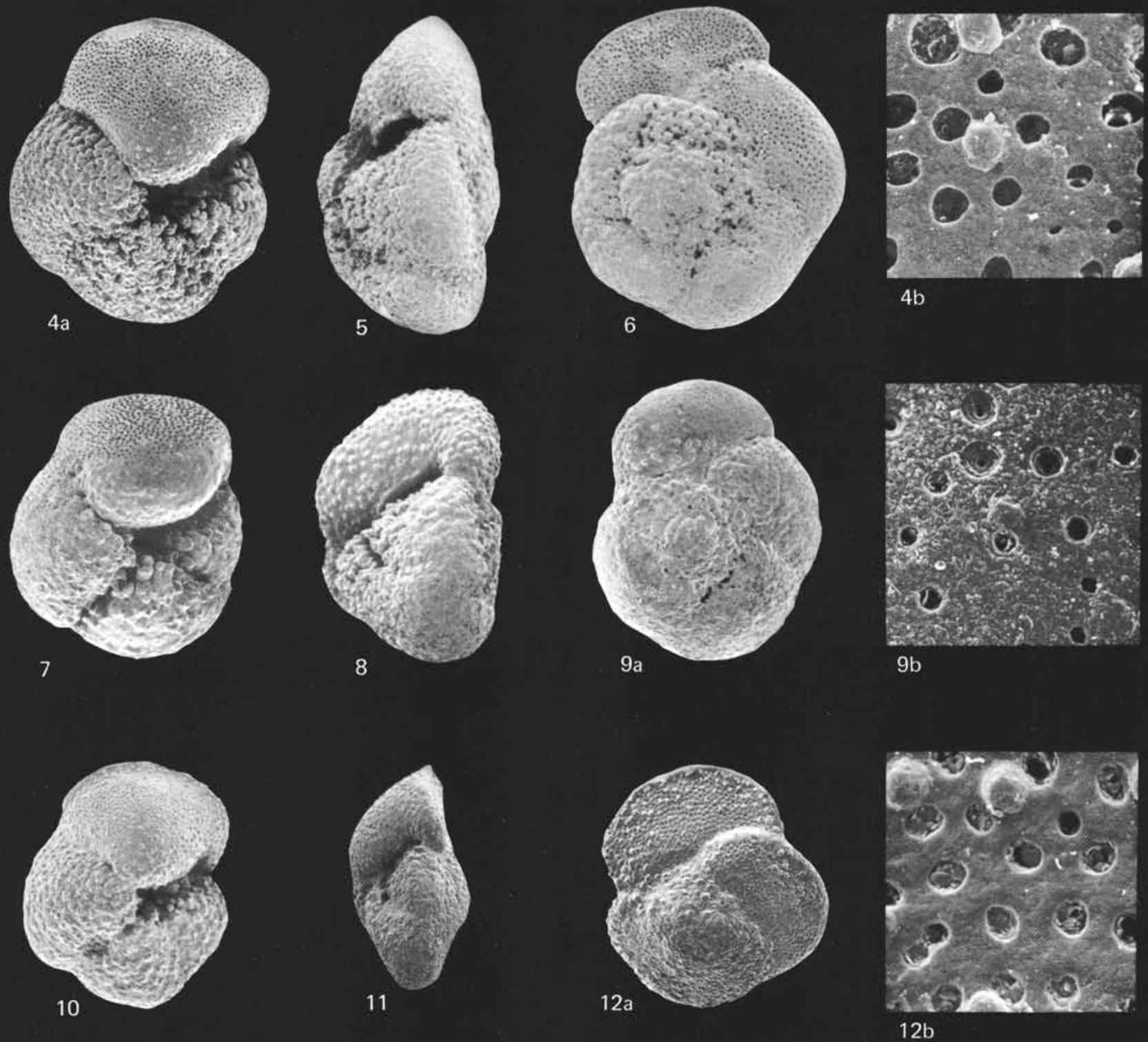


\section{PLATE 7}

Figures 1,2 Globorotalia truncatulinoides (d'Orbigny).

Sample 366-1-1 (top).

1a. Spiral view, $\times 75$.

1b. Peripheral view, $\times 75$.

2a. Umbilical view, $\times 75$.

$2 \mathrm{~b}$. Ultrastructure of the umbilical side of the last chamber, $\times 1000$.

Figures 3, $4 \quad$ Globorotalia crassaformis ssp.

Sample 366A-1, CC.

3a. Umbilical view, $\times 75$.

3b. Peripheral view, $\times 75$.

3c. Ultrastructure of the umbilical side of the last chamber, $\times 1000$.

4. Umbilical view, $\times 75$.

Figures 5-7 Globorotalia crassaformis crassaformis (Galloway and Wissler).

Sample 366A-1, CC.

5. Umbilical view, $\times 75$,

6. Peripheral view, $\times 75$.

7a. Spiral view, $\times 75$.

$7 \mathrm{~b}$. Ultrastructure of the spiral side of the last chamber, $\times 1000$.

Figures 8-10 Globorotalia triangula Theyer.

Sample 366A-3, CC.

8a. Umbilical view, $\times 75$.

$8 \mathrm{~b}$. Ultrastructure of the umbilical side of the first chamber of the last whorl, $\times 1000$.

9. Peripheral view, $\times 75$.

10. Spiral view, $\times 75$.

Figures 11-13 Globorotalia inflata (d'Orbigny).

Sample 368-1, CC.

11. Umbilical view, $\times 75$.

12. Peripheral view, $\times 75$.

13a. Spiral view, $\times 75$.

13b. Ultrastructure of the spiral side of the last chamber, $\times 1000$. 


\section{PLATE 7}
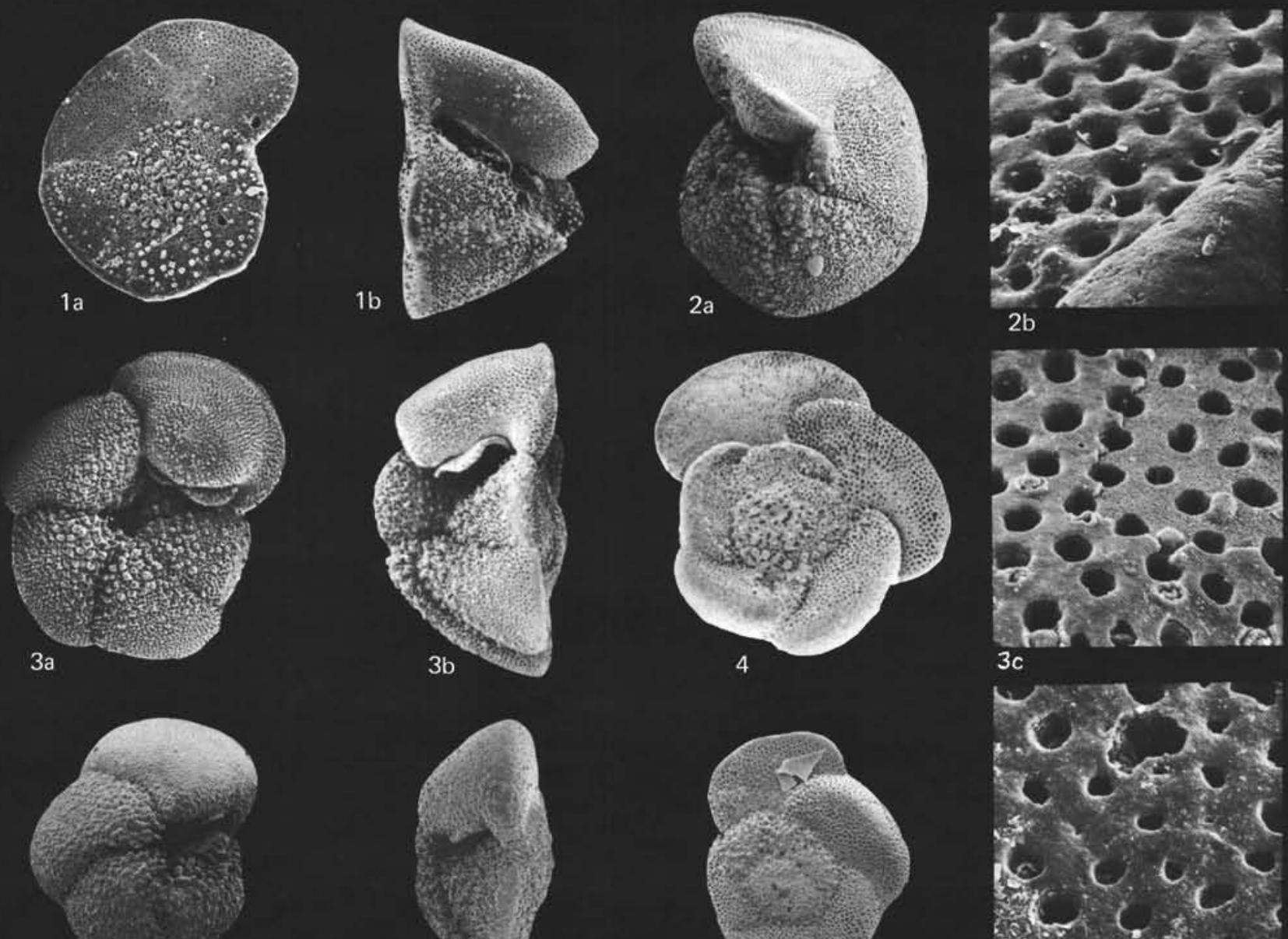

5
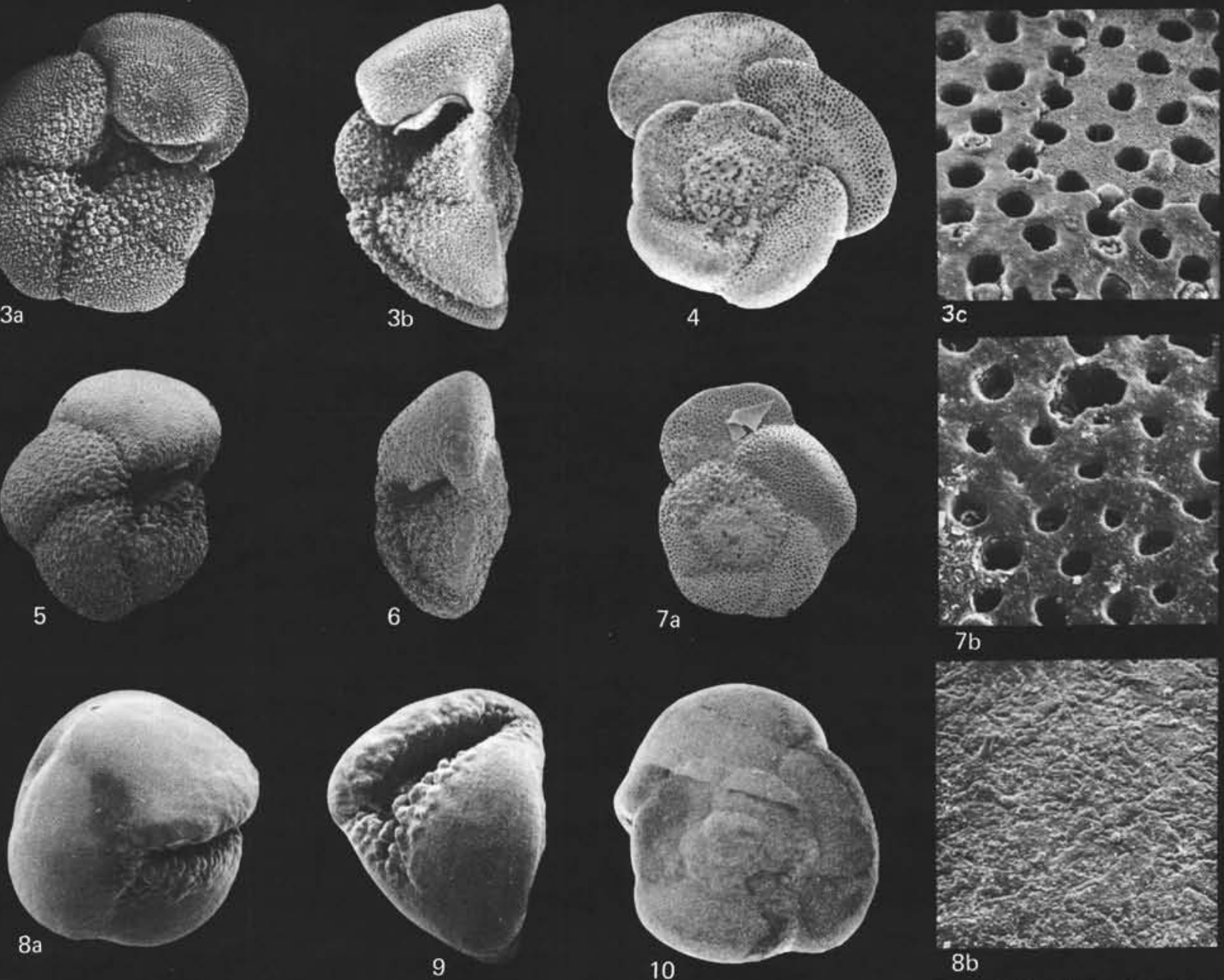

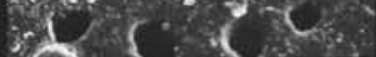
$7 \mathrm{~b}$

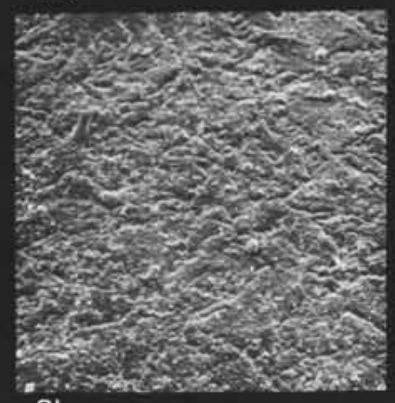
$8 b$
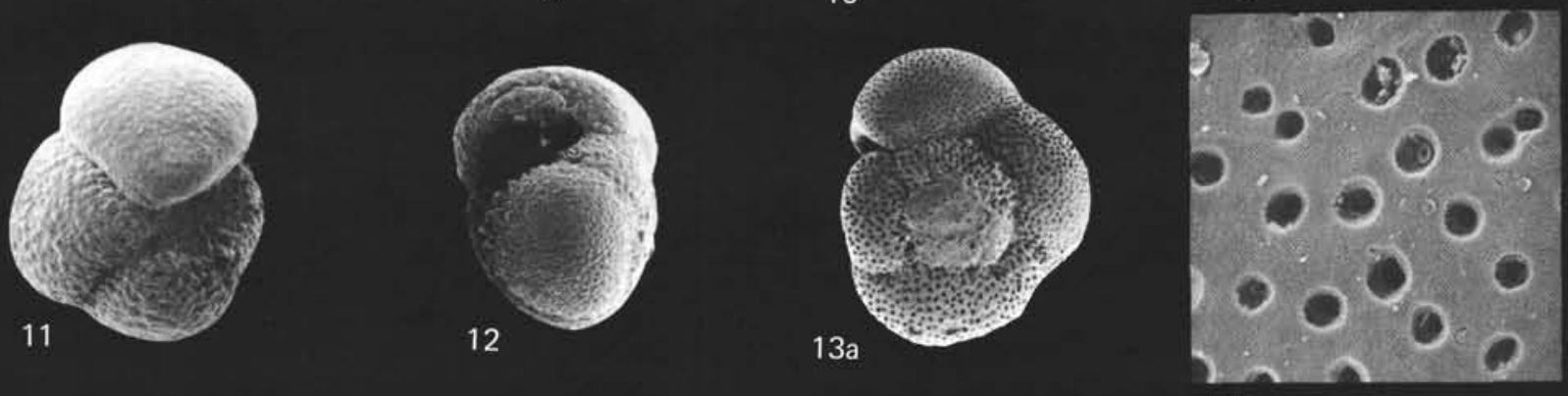


\section{PLATE 8}

Figures 1-3 Neogloboquadrina dutertrei (d'Orbigny).

Sample 366A-1, CC.

1. Spiral view, $\times 80$.

2. Peripheral view, $\times 80$.

3a. Umbilical view, $\times 80$.

3b. Ultrastructure of the umbilical side of the last chamber, $\times 1000$.

Note: Umbilical teeth attribute this specimen to the genus Neogloboquadrina.

Figure 4 Neogloboquadrina dutertrei (d'Orbigny).

Sample 366A-3-4, 68-70 cm.

4 a. Spiral view, $\times 80$.

4b. Peripheral view, $\times 80$.

4c. Umbilical view, $\times 80$.

4d. Ultrastructure of the umbilical side of the last chamber, $\times 1000$.

Note: absence of umbilical teeth and a deep open umbilicus attribute this specimen to the genus Neogloboquadrina. The general shape of the test resembles that of the genus Globorotalia.

Figures 5-7 Neogloboquadrina dutertrei (d'Orbigny).

Sample 366A-2, CC.

5. Spiral view, $\times 75$.

6. Peripheral view, $\times 75$.

7a. Umbilical view, $\times 75$.

7b. Ultrastructure of the umbilical side of the last chamber, $\times 1000$.

Note: In respect of its general shape this specimen resembles high-spired representatives of the genus Globigerina, but it is characterized by having a non spinose test.

Figures 8,9 "Globorotalia" aff. pseudopima Blow.

Sample 366A-3, CC.

8. Spiral view, $\times 75$.

9a. Peripheral oblique view, $\times 75$.

9b. Umbilical view, $\times 75$.

9c. Ultrastructure of the umbilical side of the last chamber, $\times 1000$.

Note: generic and specific belonging to this species is under discussion.

Figures 10-12 "Globigerina" pachyderma (Ehrenberg).

Sample 368-1, CC.

10. Spiral view, $\times 150$.

11. Peripheral view, $\times 150$

12a. Umbilical view, $\times 150$.

$12 \mathrm{~b}$. Ultrastructure of the umbilical side of the last chamber, $\times 1000$.

Note: absence of spinosity and the character of the umbilical area differ this species from the typical representatives of Globigerina. 


\section{PLATE 8}
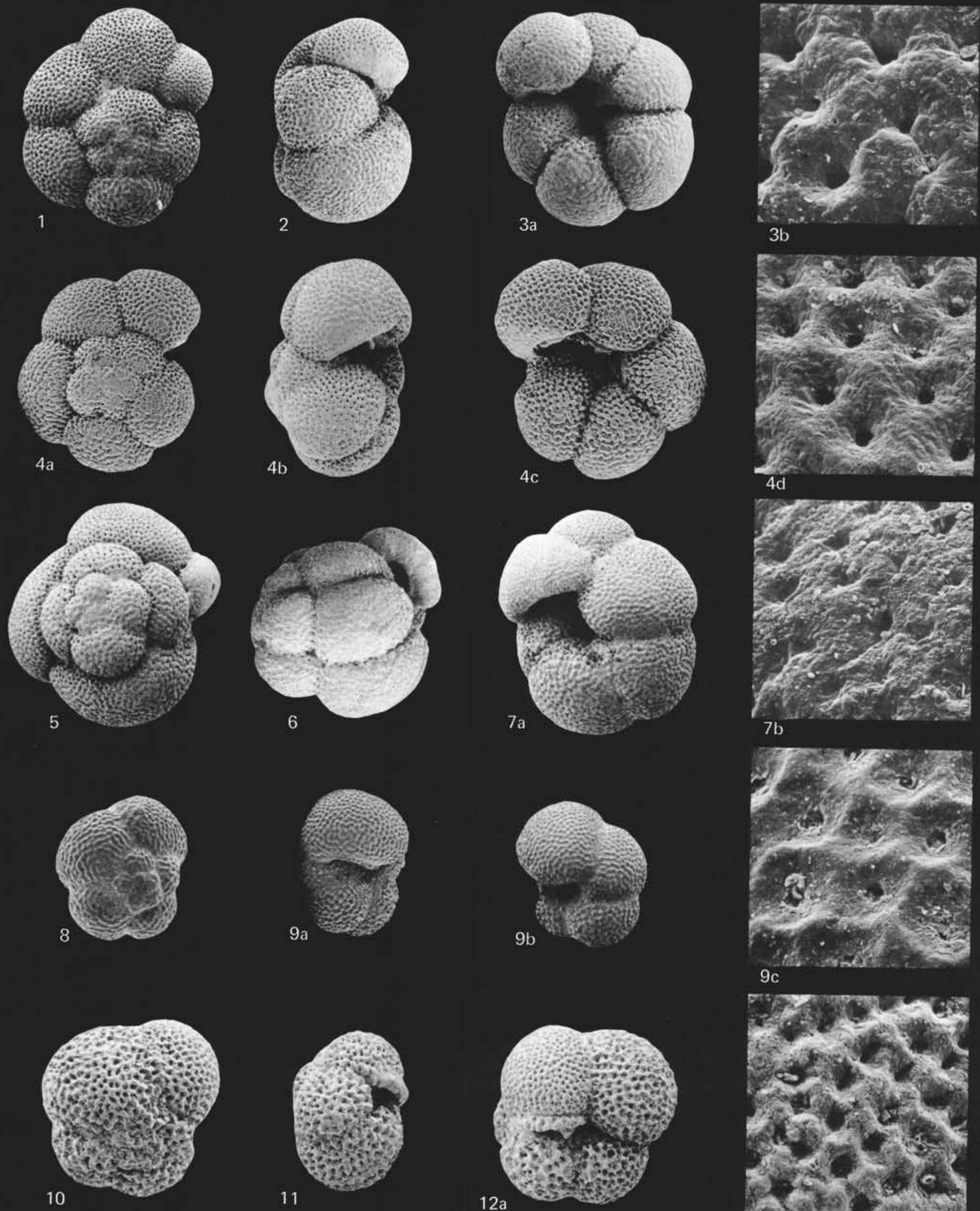

$9 \mathrm{c}$

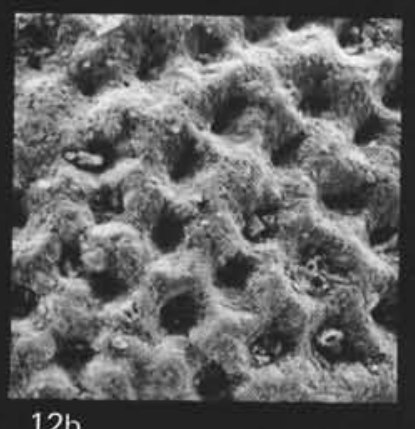

